University of Louisville

ThinkIR: The University of Louisville's Institutional Repository

Electronic Theses and Dissertations

$5-2021$

\title{
Presence of severe acute respiratory syndrome coronavirus 2 in urban streams receiving sewer overflow, Louisville, Kentucky, USA.
}

Cullen Hunter

University of Louisville

Follow this and additional works at: https://ir.library.louisville.edu/etd

Part of the Environmental Health and Protection Commons, Sustainability Commons, Urban Studies Commons, and the Water Resource Management Commons

\section{Recommended Citation}

Hunter, Cullen, "Presence of severe acute respiratory syndrome coronavirus 2 in urban streams receiving sewer overflow, Louisville, Kentucky, USA." (2021). Electronic Theses and Dissertations. Paper 3635.

https://doi.org/10.18297/etd/3635

This Master's Thesis is brought to you for free and open access by ThinkIR: The University of Louisville's Institutional Repository. It has been accepted for inclusion in Electronic Theses and Dissertations by an authorized administrator of ThinkIR: The University of Louisville's Institutional Repository. This title appears here courtesy of the author, who has retained all other copyrights. For more information, please contact thinkir@louisville.edu. 


\title{
PRESENCE OF SEVERE ACUTE RESPIRATORY SYNDROME CORONAVIRUS 2 IN URBAN STREAMS RECEIVING SEWER OVERFLOW, LOUISVILLE, KENTUCKY, USA
}

\author{
By \\ Cullen Hunter \\ B.A. DePauw University, 2017

\begin{abstract}
A Thesis
Submitted to the Faculty of the

Graduate School

in Partial Fulfillment of the Requirements

for the Degree of
\end{abstract}

\begin{abstract}
Master of Science
In Interdisciplinary Studies: Concentration in Sustainability
\end{abstract} \\ Department of Interdisciplinary Studies \\ University of Louisville \\ Louisville, Kentucky
}

May 2021 



\title{
PRESENCE OF SEVERE ACUTE RESPIRATORY SYNDROME CORONAVIRUS 2 IN URBAN STREAMS RECEIVING SEWER OVERFLOW, LOUISVILLE, KENTUCKY, USA
}

\author{
By \\ Cullen Hunter \\ B.A. DePauw University, 2017 \\ A Thesis Approved on
}

April 21, 2021

by the following Thesis Committee:

\begin{tabular}{c}
\hline Thesis Director \\
Tamara D. Sluss, Ph.D. \\
\hline Rochelle H. Holm, Ph.D. \\
\hline Donald J. Biddle, M.S.
\end{tabular}




\section{DEDICATION}

This thesis is dedicated to my partner, my family,

and

the many eyes and ears that helped me through the completion

of this thesis. 


\section{ACKNOWLEDGEMENTS}

I would like to thank my advisors Dr. Tamara Sluss, Dr. Rochelle H. Holm, and Donald J. Biddle for mentoring and encouraging me through this process. I would like to thank Aysha Tap-Ross for providing statistical analysis for this project. I would also like to thank the many related organizations that have supported me through completing the work for this thesis including the Christina Lee Brown

Envirome Institute, Kentucky Waterways Alliance, the Louisville-Jefferson County Metropolitan Sewer District, and last but not least, the University of Louisville. 


\title{
ABSTRACT
}

\author{
PRESENCE OF SEVERE ACUTE RESPIRATORY SYNDROME \\ CORONAVIRUS 2 IN URBAN STREAMS RECEIVING SEWER OVERFLOW, \\ LOUISVILLE, KENTUCKY, USA \\ Cullen E. Hunter \\ April 21, 2021
}

Pathogens may enter surface waters as they are shed in human feces and potentially delivered to surface waters via sewer overflows, particularly in the eastern United States. This study examined of the presence of fecal indicators in two forks of Beargrass Creek in Louisville, Kentucky. Surface water grab samples $(\mathrm{N}=30)$, sediment samples, water quality, and a paired wastewater surveillance study were analyzed. SARS-CoV-2 was detected in a single stream sample despite ubiquitous presence of the virus within the area in wastewater and consistent evidence of a human fecal indicator. These findings demonstrate the need for more green and gray infrastructure in the watershed to mitigate stormwater-induced overflows and reduce pathogen load to streams. 
TABLE OF CONTENTS

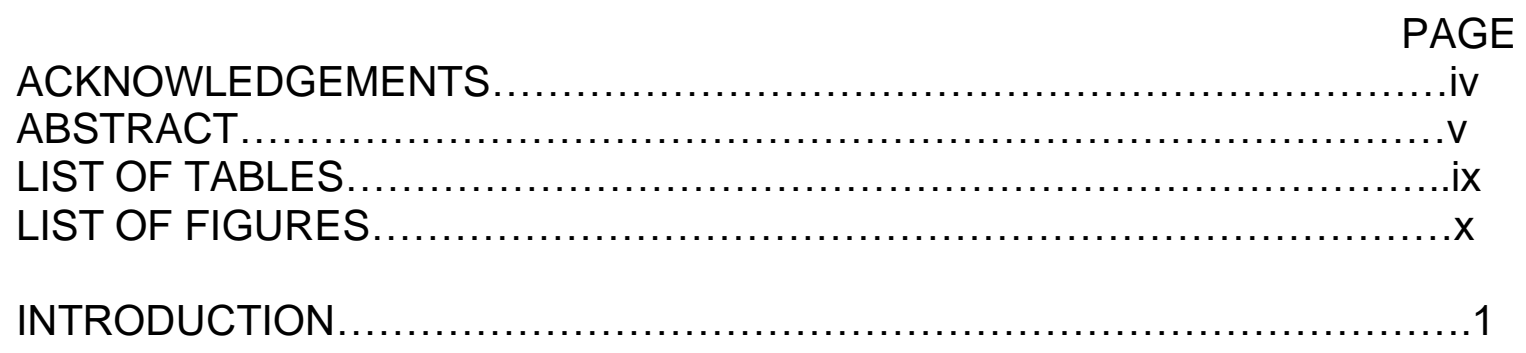

Severe Acute Respiratory Syndrome Coronavirus 2 and

Transmission.............................................................

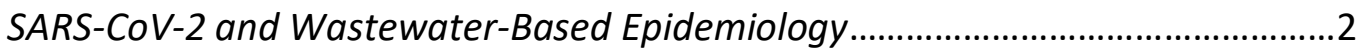

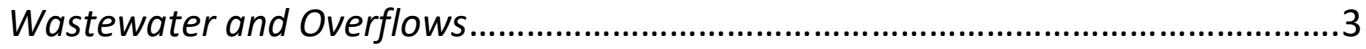

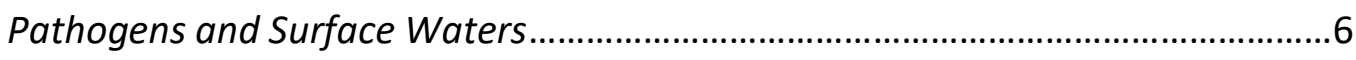

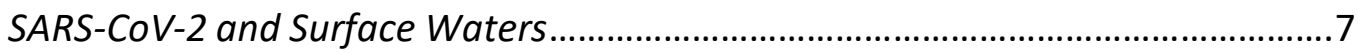

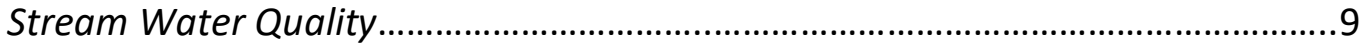

Sewer Management and Jefferson County, Kentucky, USA...................................12

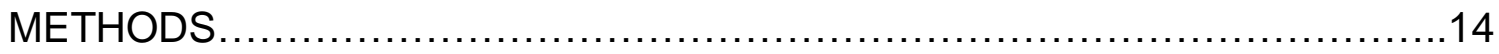

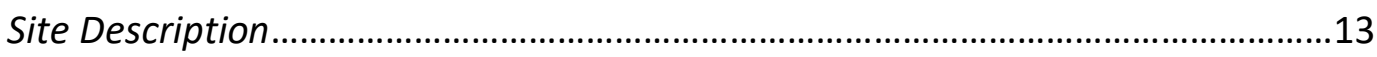

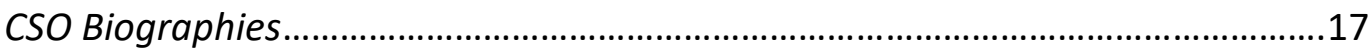

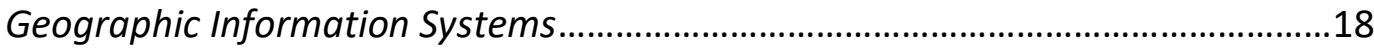

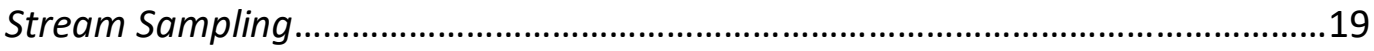

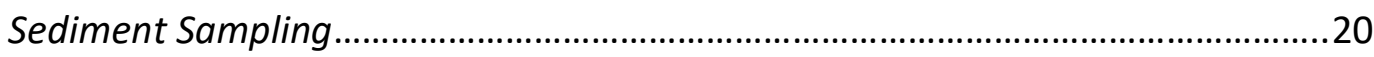

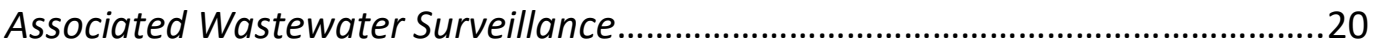


Lab Analysis.

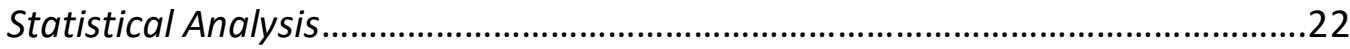

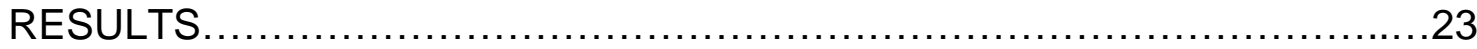

Geospatial Analysis............................................23

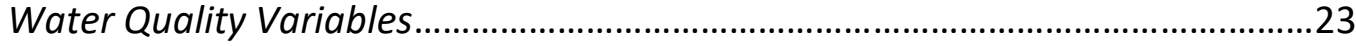

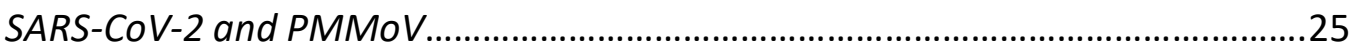

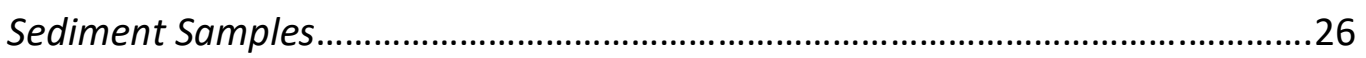

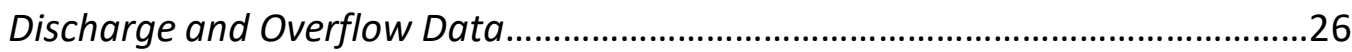

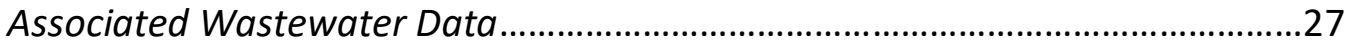

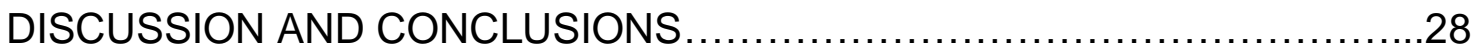

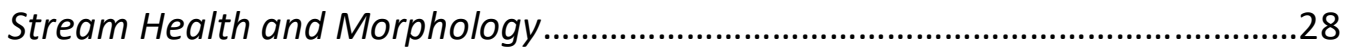

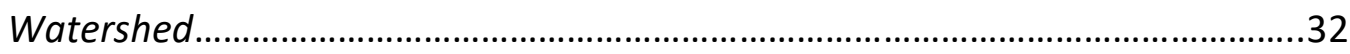

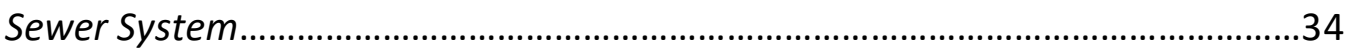

Vegetation Cover, Sanitation, and Socioeconomic Status....................................37

Associated Wastewater Surveillance ................................................................39

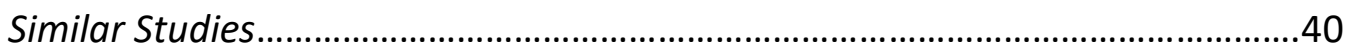

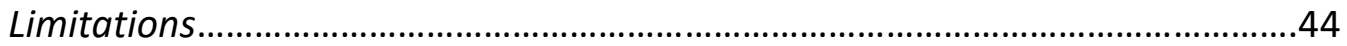

Future Research and Recommendations............................................................45

Wastewater Based Epidemiology and Beyond ......................................45

Stormwater and CSO/SSO Discharge Mitigation ....................................47

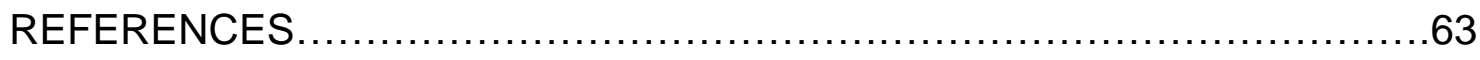

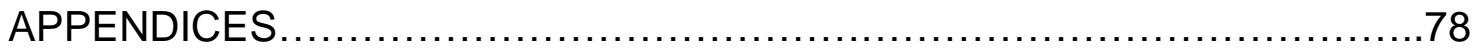




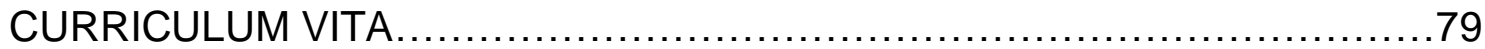




\section{LIST OF TABLES}

TABLE

PAGE

1. Existing literature on the presence of SARS-CoV-2 in surface water .51

2. Land use of the Middle and South Forks of Beargrass Creek.... 52

3. Mean Temperature (degrees Celsius) .52

4. Results of Sediment Samples on Middle Fork

.52

5. Combined Sewer Overflows and Sanitary Sewer

Overflows .53

6. Wastewater data from associated surveillance study .53

7. National Land Cover Dataset (NLCD) land use percentages from 2016 in the Middle and South Fork Watersheds of Beargrass Creek. .54

8. NLCD Impervious Surface Cover in Middle and South Fork Watersheds of Beargrass Creek..............................................................54 


\section{LIST OF FIGURES}

FIGURE

PAGE

1. Sample Site Location Map..................................................55

2. MSD and USGS Stream Monitoring Locations..............................56

3. Land Use of Middle and South Forks of Beargrass Creek.....................57

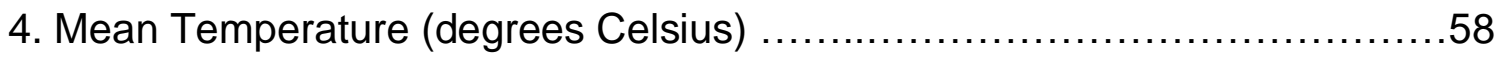

5. Mean Dissolved Oxygen (percent saturation) ..............................58

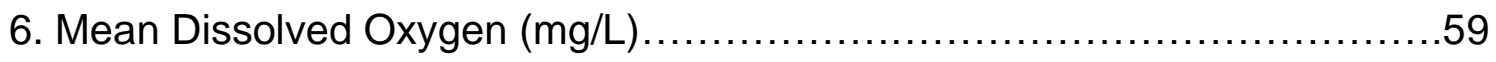

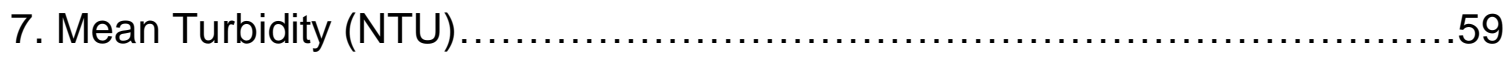

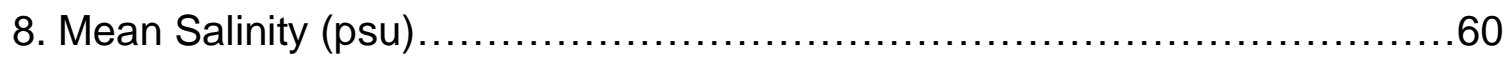

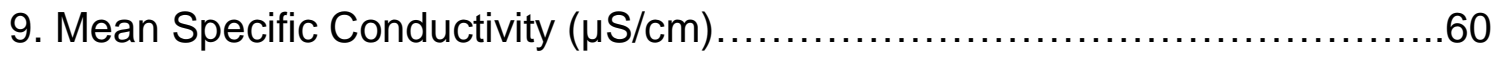

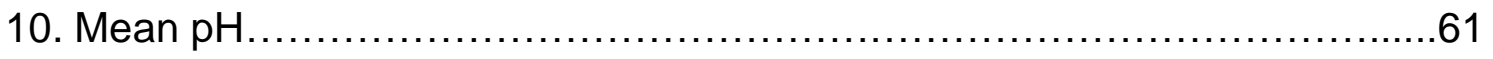

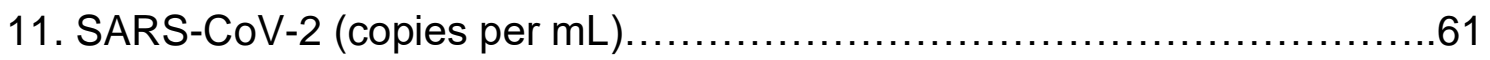

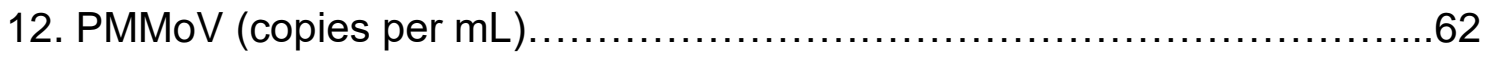

13. Daily Stream Discharge of Middle and South Forks.......................62 


\section{INTRODUCTION}

\section{Severe Acute Respiratory Syndrome Coronavirus 2 and Transmission}

Severe acute respiratory syndrome coronavirus 2 (SARS-CoV-2) is part of a group of coronaviruses which are characterized by enveloped ribonucleic acid (RNA) with spikes resembling crowns on the exterior of the outer envelope (Bogler et al. 2020; Naddeo and Liu 2020). SARS-CoV-2, the virus that causes COVID-19, includes disease symptoms such as mild to severe fever or chills, cough, shortness of breath, and diarrhea (CDC 2021b). It was first identified in December of 2019 in Wuhan, China, and has taken over 560,000 lives in the US as of April 2021 (Centers for Disease Control [CDC] 2021a). SARS-CoV-2 is spread primarily by close person-to-person contact through inhaled respiratory droplets, or through the respiratory droplets that linger in the air and are then inhaled by someone who was not in direct close contact with the person carrying the virus. In rare instances, the virus can be transmitted from contaminated surfaces where the respiratory droplets have landed and then subsequent contact with the eyes, nose, or mouth (CDC 2021c). 


\section{SARS-CoV-2 and wastewater-based epidemiology}

Beyond respiratory system characteristics, humans shed SARS-CoV-2 in feces, thus testing the wastewater for concentrations of SARS-CoV-2 RNA can be used as an indicator of community virus rates (Medema et al. 2020; Gerrity et al. 2021). Wastewater-based epidemiology (WBE) has been a useful indicator of the presence of SARS-CoV-2 in a community, even before disease outbreaks happen (Hart and Halden 2020; Daughton 2020; Ahmed et al. 2021; Environmental Protection Agency [EPA] 2020a, CDC 2021d).

A key component to WBE is the ability to spatially track the compound of interest, in this case the SARS-CoV-2 virus. Piped sewer systems with a geographically defined catchment area allow the analysis of the virus in relation to the population size the piped sewage system serves. This analysis can then inform the prevalence of the virus within a defined area (Nourinejad, Berman, and Larson 2020; Sims and Kasprzyk-Hordern 2020).

WBE has been used all over the world including in Australia, India, Japan, the United States (Ahmed et al. 2020; Aurora et al. 2020; Randazzo et al. 2020; Hata et al. 2021; Gonzalez et al. 2020). Measuring the presence of SARS-CoV-2 via wastewater can be used as an indicator of cases that are both symptomatic and asymptomatic without having to test each person in the community (Bivins et al. 2020). WBE can also be used to highlight the presence of SARS-CoV-2 variants within a community (Fontenele et al. 2021). 


\section{Wastewater and Overflows}

Wastewater can end up in waterways, raising additional pollution and transmission concerns via three main routes: Combined sewer overflows, sanitary sewer overflows, and straight pipes. In the 1800 s, combined sewers were introduced as a way to carry rainwater and sewage in one underground piped system away from homes and businesses, along with the impetus to keep sewage out of waterways to keep streams and rivers a viable option for clean drinking water (Tibbetts 2005; Recktenwald 2017). Combined sewer overflows (CSO) is a route where when the system is over capacity, such as during a high rainfall event, the system is designed to release at specific points leading to untreated sewage draining into the nearby environment (Hata et al. 2014; Day and Seay 2020; Yates et al. 1984). Initially, these pipes emptied directly into rivers and other waterways until sewage treatment plants were introduced to treat the sewage before it is emptied into waterways.

Furthermore, combined sewers are designed so that when there are heavy rain events or large quantities of snowmelt, the excess mix of stormwater and sewage escapes at the designated points which are manholes at ground surface instead of backing up into homes (Tibbetts 2005). In 1994, the Environmental Protection Agency created the CSO Control Policy through the National Pollutant Discharge Elimination System (NPDES) that requires communities to reduce their CSOs while also cooperating with cities so that they can attain those criteria. The policy also requires the implementation of both short-term and long-term goals to reduce the discharges (Tibbetts 2005). 
Especially during wet weather events, combined sewer overflows pollute the nearby waterways, often indicated by the presence of Escherichia coli bacteria following the overflow events. A study in 2007 conducted surveillance of E. coli in Lake Michigan and found dramatically increased levels of the bacteria following rain events at CSO outfall locations, and in lighter precipitation years, the bacteria levels were much lower (McLellan et al. 2007). Exposure to these waters polluted with fecal bacteria via recreational activities, like swimming or wading, are associated with higher rates of gastrointestinal symptoms, skin infections, and even symptoms of the upper respiratory tract (EPA 1983).

The U.S. Environmental Protection Agency has regulations on combined sewer overflows originating from the "Combined Sewer Overflow (CSO) Policy" added to the National CSO Control Strategy from 1989. The "Combined Sewer Overflow Policy" entails enforcement and permitting requirements to ensure compliance with the Clean Water Act of 1972 (EPA 2020c). Requirements include the implementation of the 'nine minimum controls' to mitigate CSOs such as regular maintenance, pollution prevention, monitoring of the impacts of CSO controls, and prohibition of combined sewer overflows during dry weather. Permittees are also required to develop a long-term control plan to become fully compliant with the Clean Water Act taking into account site, cost effectiveness, and water quality standards (EPA 1994).

Sanitary sewer overflows (SSO) are purely untreated sewage overflows. These prohibited overflows are even more dangerous than CSOs as they are not diluted by stormwater, and occur between 23,000 and 75,000 times per year in 
the United States (EPA 2020b). Around the time when the Federal Water Pollution Control Act of 1948 became the Clean Water Act of 1972, Section 301 prohibits SSOs entirely (Strifling et al. 2005). Overflows resulting in contaminated surface waters present issues for communities with lower sanitation practices or limited drinking water sources because they present a risk of exposure to fecal matter carrying bacteria or viruses (Bhowmick et al. 2020).

For example, in a 15-year study on urban Baltimore, Maryland, streams, annual nitrate and phosphate increases were associated with sanitary sewer overflows and their duration of overflow, contributing to poorer water quality downstream. Precipitation was a huge driver of these SSO events, further enforcing the importance of the issue of overflows (Reisinger et al. 2018).

In an effort to reduce overflows from excess stormwater, around the 1970s, the EPA pushed for 'separate' sewers such that stormwater isn't unnecessarily treated as wastewater, and wastewater pipes aren't overwhelmed by excess stormwater (Strifling et al. 2005). During dry weather conditions, this system generally operates without malfunction, however during wet weather, stormwater can enter the 'separate' sewer system via cracks in pipes, manhole covers, and other defects that cause backups and overflow (Strifling et al. 2005; City of Milwaukee Department of Public Works n.d.). Household downspouts connected directly to sewer lines or discharging directly to impervious surfaces can also contribute to a rapid influx of stormwater into the sewer system and surface runoff (Taguchi et al. 2018; Carmen et al. 2016). 
Straight pipes are another pathway whereby untreated sewage can reach streams or other bodies of water, both globally and in the United States. There are many communities throughout the states that rely heavily on straight pipes as the method of waste disposal (The Kentucky Water Resources Institute 2000). Clay soils, a high water table, and karst topography characterized by unsuitable soils can prevent the usage of septic systems, and instead people must resort to straight pipes if they are unable to secure any on-site wastewater treatment (Maxcy-Brown et al. 2021; Bockheim and Hartemink 2012; EPA 2002). Despite straight pipes being illegal, because on-site treatment or proper disposal can be financially prohibitive, especially in areas of high poverty, sewage discharge via straight pipes still occurs (Stoner 2017). In addition, faulty wastewater pipes that can leak or discharge into nearby streams, and failing septic tanks are also methods where sewage can be illicitly discharged and contribute to stream pollution (The Kentucky Water Resources Research Institute 2000).

\section{Pathogens and Surface Waters}

Human pathogens can contaminate groundwater, marine and coastal aquatic systems, and surface waters through various forms of point and nonpoint source pollution. For example, E. coli was significantly correlated with stormwater conditions versus baseflow stream discharge conditions in a case study from 2018 (Wang et al. 2018). Combined sewer overflows have been found to carry giardia, and contact with these contaminated waters could pose a risk of infection (Arnone and Walling 2006). 
Another virus, Pepper Mild Mottle Virus (PMMoV) which is a singlestranded, non-enveloped plant virus, has been detected in many sources of water including marine and coastal aquatic systems, rivers, and wastewater. It has been used as a human fecal indicator and its use has grown over the years as it is abundant in human feces, but rarely found in animal feces (Sydmonds et al. 2019). Its widespread detection makes this an ideal marker for human input in aquatic systems receiving wastewater input (Kitajima et al. 2018).

In addition to the potential viruses entering surface waters through wastewater discharges or overflows, there are also the COVID-19-related drugs used to treat patients who contracted it such as fever reducers, chloroquine, and other pharmaceuticals. Pollution from disinfection chemicals can also pose a threat to the organisms in the stream. These chemicals could have harmful biological impacts to the stream ecosystem, and are an area of potential further study (Bandala et al. 2021).

\section{SARS-CoV-2 and Surface Waters}

To date, there are limited studies investigating the presence of SARSCoV-2 in wastewater and associated surface waters that may be impacted by CSOs, SSOs or straight pipes. In a literature review of the presence of SARSCoV-2 in surface waters, there are few studies globally on this subject (Table 1). A study in Italy, and similarly one in Japan, tested both untreated and treated wastewater near surface waters that receive untreated sewage input to learn more about the prevalence and distribution of the disease in streams and rivers 
(Rimoldi et al. 2020; Haramoto et al. 2020). In another study, surface waters of Ecuador were sampled for SARS-CoV-2 during a peak in their cases of COVID19 and found that in each sampling location SARS-CoV-2 RNA were within the level of detection (Guerrero-Latorre et al. 2020).

While there are still relatively limited data on SARS-CoV-2 in surface waters and other environmental conditions, using other coronaviruses may help predict the behavior of SARS-CoV-2 in similar conditions. Factors including the $\mathrm{pH}$ level, temperature of the water, and concentration of suspended solids and organic matter may help predict the presence and prevalence of coronaviruses in water (Tran et al. 2020). Research on the persistence of SARS-CoV-2 suggests in room temperature tap water $\left(20^{\circ} \mathrm{C}\right)$, the viable virus reduces $90 \%$ in 1.7 days and in wastewater 1.5 days at room temperature. At $50{ }^{\circ} \mathrm{C}$ the virus has shown to be viable for 15 minutes, and at $70^{\circ} \mathrm{C}$ for 2.2 minutes in wastewater (Bivins et al. 2020).

The infectiousness of the virus in environmental conditions is also still in its early days of research (Bandala et al. 2021). However, exposure to UV irradiation, ozonation, chlorination, and sodium hypochlorite have been shown to eliminate the virus in wastewater systems (Sunkari et al. 2021). Particulate matter, and its constituents like trace elements, minerals, or organic compounds, may impact the adsorption and resulting transmission of the virus on these particles. More research is needed on the relationship of constituents of particulate matter, and whether it may help or hinder the transmission of the viable virus (Wathore et al. 2020). 


\section{Stream Water Quality}

Sewer overflows, along with other factors of input such as surrounding land use, percentage of impervious surfaces, and stream channel alterations, can result in fluctuations of nutrients that impact the health of the streams (Walsh et al. 2005; Grimm et al. 2005). There are a number of water quality variables to consider when evaluating the health of a stream, especially in assessing if the stream is suitable for primary contact recreation, evaluating the impacts of combined sewer overflows, or monitoring another anthropogenic impact.

For example, an increase in nitrogen and phosphorus in streams from anthropogenic activities like burning fossil fuels, or runoff from agricultural pesticide use can induce eutrophication (Carpenter et al. 1998). Nitrogen and phosphorus regulate the primary productivity of freshwater systems, and can also be impacted by the surrounding conditions like light availability, hydrology, and food web structure of the specific site (Smith et al. 2006).

Similarly, ammonia, a form of nitrogen, in high levels can become toxic for aquatic organisms as ammonia is a waste product of fish metabolism. Excessive ammonia in the system and within their metabolic system leads to a hindrance in the fish excreting ammonia, and too much uptake of ammonia (Egnew et al. 2019). Typically ammonia enters streams in the form of untreated or treated wastewater, and this nutrient can also play a role in controlling $\mathrm{pH}$ by the ratio of unionized to ionized ammonia (Wang et al. 2020). 
These nutrient loads of nitrogen, phosphorus, and ammonia, either from wastewater or other sources such as industrial pollutants, agricultural irrigation, and surface water runoff containing fertilizers, can induce eutrophication in surface waters (Yang et al. 2008). Eutrophication, where algae become overabundant due to the availability of excess nutrients and subsequently decompose, can decrease the dissolved oxygen in the water as a result of the decay of the algae, and cause fish kills. Even some of these algae blooms, specifically by Cyanobacteria, can release toxins that are harmful to humans (USGS 2020). Other conditions like temperature, light penetration, hydrodynamics of the water body, and existing microbial activity can impact whether an algal bloom occurs (Yang et al. 2008).

Temperature is an important water quality indicator of stream health as it influences respiratory and circulatory systems of aquatic biota, among other processes. Sudden changes in temperature may limit metabolic functions, and even input of extreme temperatures can be lethal for aquatic life (Brett 1956). Runoff from surfaces like parking lots (Herb et al. 2008), and discharge from wastewater effluent can be a source of thermal pollution for the stream, and even change the overall temperature of the stream (Kinouchi et al. 2007). In relation to SARS-CoV-2, temperature is a factor in the infectivity of the virus where higher temperatures increasing the rate of decay. In river water matrices, SARS-CoV-2 has been shown to be viable at T90 values for 1.9 days at $24^{\circ} \mathrm{C}$ and 7.7 days at $4{ }^{\circ} \mathrm{C}$ (de Oliveira et al. 2021). 
Dissolved oxygen, another water quality indicator, is influenced by oxygen demands from biological and chemical sources, suspended solids, algae and bacteria, $\mathrm{pH}$, specific conductance, and temperature. In this way, dissolved oxygen is often used to evaluate water quality of streams, as an increase in other parameters often contributes to a decrease in dissolved oxygen concentration and overall water quality (Vicente et al. 2011).

Turbidity is a measure of suspended solids in a stream and often increases after rain events as more suspended material enters the body of water, either through runoff or through sewer overflow input. Incorporating turbidity analysis with levels of human fecal indicators may shed light on the relationship between the length of rain events, the amount of fecal indicator present, and how turbid the water is (Viviano et al. 2017). Higher levels of turbidity can lead to decreased penetration of light in the water column, temperature changes, and deposition of sediment. These suspended solids can also carry with them harmful chemicals such as heavy metals and pesticides, and if the particles are high in organic matter, their decomposition in the stream can deplete oxygen (Bilotta and Brazier 2008).

Salinity and specific conductance are related to the amount of dissolved ions in the water in terms of the ability to conduct electrical current. Sources of these ions can come from more natural processes like weathering of rocks or in small amounts from rainwater. Other sources of dissolved ions can come from anthropogenic practices like irrigation and agriculture, acting as a secondary source of salinization to streams and rivers (Cañedo-Argüelles et al. 2013). 
These secondary sources of dissolved ions from catchment areas can also influence $\mathrm{pH}$ and specific conductance in urban streams due to the land use and land cover of the watershed (Conway 2007). Percent impervious surface in a watershed, such as concrete, has been shown to be highly correlated with elevated levels of specific conductance, especially when concrete is a primary material of grey infrastructure that carries stormwater (Tippler 2012).

SARS-CoV-2 has been shown to be infectious at a wide range of $\mathrm{pH}$ values, up to six days from a $\mathrm{pH} 5$ to $\mathrm{pH} 10$, but more extreme values of $\mathrm{pH} 2$ and $\mathrm{pH} 3$ as well as $\mathrm{pH} 11$ to $\mathrm{pH} 12$, the virus was only viable for one to two days in a lab experiment investigating viability (Chan et al. 2020). $\mathrm{pH}$ is important to stream water quality as streams that are too acidic, or receive pollutants that induce acidification like acid precipitation, can affect the assemblages of invertebrates, the amount of leaf litter breakdown, and the resulting productivity and function of the ecosystem (Simon et al. 2009).

\section{Sewer Management and Jefferson County, Kentucky, USA}

Point sources of pollution are hazardous to the receiving bodies of water, including both sewer overflows that are strictly untreated sewage, and those not diluted with storm water. Due to the sewers often being overwhelmed with stormwater combining with untreated sewage, Beargrass Creek, even since the 1980s has received these untreated overflows (MSD 2012a, MSD 2012b; Ruhl and Jarrett 1999). Specifically concerning Middle and South Forks of Beargrass 
Creek, CSO and SSO input is common, including in areas that are close to recreational sites.

The sample locations of this study are in proximity to a parallel wastewater study for SARS-CoV-2 surveillance (Fontenele et al. 2021; Yaeger et al. 2020; Holm 2021). These paired wastewater and surface water sites in Beargrass Creek, one in the Middle Fork, and one in the South Fork, were chosen to sample. The objective of this study is to investigate the prevalence of SARSCoV-2 RNA copies in the Middle and South Forks of Beargrass Creek that receives CSO and SSO inputs. This study also examines the relationship between heavy rainfall, documented discharge from adjacent CSO/SSOs, stream water quality, watershed management, and the presence of SARS-CoV-2. The hypothesis for this study was finding evidence of SARS-CoV-2 RNA in the Middle and South Forks of Beargrass Creek after sewer overflow events caused by heavy rainfall, and when there was evidence of SARS-CoV-2 in the paired wastewater sampling sites. 


\section{METHODS}

\section{Site Description}

Beargrass Creek Watershed, in Jefferson County, Kentucky, is part of the larger Lower Ohio - Salt River Watershed (Kentucky Watershed Viewer n.d.). Beargrass Creek Watershed is comprised of three forks: Muddy, Middle, and South. The two sample sites are located on the Middle Fork at 38 $144^{\prime} 02.7^{\prime \prime} \mathrm{N}$, $85^{\circ} 41^{\prime} 05^{\prime \prime}$ W, and on the South Fork $38^{\circ} 12^{\prime} 54.5^{\prime \prime} \mathrm{N}, 85^{\circ} 42^{\prime} 14.2^{\prime \prime}$ W of Beargrass Creek.

The Middle Fork of Beargrass Creek watershed encompasses about 65 square kilometers, is south of the Muddy Fork, and is bordered by several parks within Jefferson County, including Cherokee Park, and Seneca Park further upstream. The South Fork of Beargrass Creek contains about 70 square kilometers of Jefferson County and is south of the Middle Fork. This fork flows through a portion of downtown Louisville before it empties into the Ohio River. There are two USGS monitoring stations on the South Fork of Beargrass Creek (MSD 2012b, Figures 1 and 2). The sample site is also downstream of Joe Creason Park, part of the Olmsted Parks Conservatory, and Beargrass Creek State Nature Preserve (Figure 3). 
Impervious surfaces, overflow input from CSOs and SSOs, and stream bank erosion are factors that currently contribute to the water quality issues in this stream (MSD 2012a; MSD 2012b). There are currently 121 CSOs in Jefferson County and 119 SSOs (LOJIC 2020; MSD 2021a). Overflows in Jefferson County are monitored by a real-time control system deployed by the Louisville/Jefferson County Metropolitan Sewer District (MSD) using rainfall data and weather forecasting to predict sewage flow rates and volume (MSD 2019). This technology informs MSD to prioritize certain overflows, reducing the potential impacts of discharges on the most vulnerable bodies of water including Beargrass Creek (Tao et al. 2020; US EPA v. MSD 2005).

MSD signed a Consent Decree in 2005 with the US Department of Justice, U.S. Environmental Protection Agency, and the Kentucky Department of Environmental Protection to develop an Integrated Overflow Abatement Program (IOAP) to mitigate the unauthorized combined sewer and sanitary sewer overflows (EPA 2021). The Consent Decree requires the permittees to implement nine minimum controls including proper and regular maintenance to the CSOs, reviews and modifications to the CSOs, pollution prevention, and public notification of the sewer overflow occurrences and sewer overflow impacts (EPA 2021). In this agreement, MSD pledged a number of projects and capital improvements including a response and cleanup protocol to sewer overflows, publicly making available the documentation of occurrence and volume of discharges, and the elimination of a number of CSOs and SSOs (US EPA v. MSD 2005). 
MSD has completed a number of projects reducing the impacts of stormwater to waterways including stream restoration using weirs to restore meandering flows and other green infrastructure throughout Jefferson County. A wet weather relief storage basin upstream of the Middle Fork sampling location is in its planning phase at the time of this article, and there have been dam modifications to CSO 108 to reduce the number of overflows at this location (MSD n.d.).

Beargrass Creek, and the surrounding land, has been the focus of a number of improvement projects outside of MSD including the creation of the Beargrass Creek Nature Preserve dedicated in 1982. This Nature Preserve consists of 41 acres of urban forestry on the South Fork of Beargrass Creek near the South Fork sampling location of this study (Kentucky Energy and Environment Cabinet 2019). Beargrass Creek has also been a part of several greenway construction projects connecting areas of Beargrass Creek previously not accessible by bikers, walkers, and hikers (Louisville-Jefferson County Metro Government 2021). It has been demonstrated that the relationship between the intensity and duration of rain events to overflow or non-overflow events from a combined sewer on the South Fork of Beargrass Creek (Day and Seay 2020).

Some areas of the Beargrass Creek watershed fall under the 303d list for aquatic life and recreational impairment due to the impacts in the urban area around the creek (MSD 2012a). In the Middle Fork, according to the Kentucky Watershed Viewer, the entire stream does not support swimming, or any form of primary contact recreation due to the concentrations of fecal coliform being 
higher than the water quality standards, and $85 \%$ does support aquatic life due to channelization, problems with nutrient runoff from sanitary sewers and urban runoff (Kentucky Water Health Portal 2001, 2009). In the South Fork, similarly the entire stream also does not support swimming or primary contact recreation, and only about $20 \%$ partially supports aquatic life (Kentucky Water Health Portal $2001,2009)$. Despite these circumstances, there is a variety of plant and animals which these waterways support.

\section{$\underline{\text { CSO Biographies }}$}

This study examined CSOs and SSOs that were directly adjacent to the main branches of the Middle and South Forks of Beargrass Creek two stream miles upstream from each sample site. Any CSO or SSO not directly adjacent to the stream, and therefore not a potential direct point-source pollution source, was excluded from analysis. Measurement of five stream miles was determined using ArcGIS desktop software version 10.6.1 and LOJIC (ArcGIS Desktop 2018; LOJIC Online 2020).

For the Middle Fork of Beargrass Creek, the sampling location can potentially be affected within five stream miles of the sample site are Sewer Manhole SSO 45900 and Sewer Manhole SSO ISO21A-SI. Overflows at SSO 45900 were first discovered in 2011 (MSD 2010a). The receiving stream for SSO 45900 is a tributary of Beargrass Creek but is still within the Middle Fork Watershed. In 2015, this SSO discharged 612,000 gallons of raw sewage, however in 2013, there were no documented discharges. At SSO ISO21 A-SI, in 
2015 there were 46 documented overflows with a total volume of 100 gallons. (MSD 2010b).

For the South Fork of Beargrass Creek, CSOs that could contribute to this sample site within five stream miles include CSO 108, Sewer Manhole SSO 51594, Sewer Manhole SSO 23211, and Sewer Manhole SSO 30681. In a report from 2014, CSO 108 overflowed 21 times per year with an average duration of 1.4 hours and average discharge volume of 0.38 MGal per incident (MSD 2013). At Sewer Manhole SSO 51594, the first reported overflow was in 2005, and ranging from about 50-60 overflows between the years 2011 and 2015 (MSD 2010d). Sewer Manhole SSO 23211 has overflowed ranging from 29 to 36 times each year from 2011 to 2015 . At this SSO, the manual sluice gate is open to minimize flooding of the residential basements as part of this catchment area (MSD 2010e). The first reported overflow for Sewer Manhole SSO 30681 was in 2004 , and is monitored during wet weather events (MSD 2010f).

\section{Geographic Information Systems}

Basemaps and feature data were obtained from the University of Louisville Center for Geographic Information Sciences, and the Louisville and Jefferson County Information Consortium (LOJIC) for Louisville's Metropolitan Sewer District. CSO/SSO point shapefiles, MSD/USGS monitoring station shapefiles, land cover data, watershed shapefiles, major road shapefiles, and county polygon shapefiles were obtained from these sources. ArcGIS desktop version 
10.6.1 was used for all the geospatial processing and map creation (ArcGIS Desktop 2018).

Land cover classification and imperviousness data were obtained from the National Land Cover Database (MRLC 2016) and used to derive land cover and impervious surface percentages for the Middle and South Fork Watersheds. Clipped to both watersheds, the land cover and impervious surface raster datasets were converted to polygon feature data and summarized by category to obtain percentages based on area to generate the tables of comparison between the Middle and South Fork watersheds (Table 7, Table 8).

\section{Stream Sampling}

A total of 15 samples were taken at each the Middle Fork and South Fork of Beargrass Creek, five replicates per location on each sampling date $(\mathrm{N}=30)$. At each sampling event, a Hydrolab (Hach, Loveland, CO) was used to obtain water quality data at each site for each replicate. The Hydrolab was immersed in the water, taking care to not disturb any sediment and artificially increase turbidity. Temperature $\left({ }^{\circ} \mathrm{C}\right)$, specific conductivity $(\mu \mathrm{S} / \mathrm{cm})$, salinity (psu), dissolved oxygen (percent saturation), concentration of dissolved oxygen $(\mathrm{mg} / \mathrm{L}), \mathrm{pH}$, and turbidity (NTU) were all measured with the Hydrolab for each replicate. Nutrient concentrations of nitrite $(\mathrm{mg} / \mathrm{L})$ and nitrate $(\mathrm{mg} / \mathrm{L})$, phosphate $(\mathrm{mg} / \mathrm{L})$, and ammonia (ppm) were sampled with nutrient strips (Hach, Loveland Colorado, Products $2745425,2755325,2757150$ ) test strips twice at each location using a 
separate dedicated bottle. Date, time, air temperature, and general weather (cloudy/clear day, light rain, etc.) were also recorded for each site.

Simultaneously with the Hydrolab, five grab sample replicates in a $500 \mathrm{ml}$ high density polyethylene bottle (Ward's Science, Rochester, NY, Product number 470191-308) were taken within one meter of the sample location from the stream bank, flushing each bottle twice with stream water before sample collection. Sample bottles were sealed with electrical tape, bagged in plastic baggies, and chilled with disposable ice packs in a cooler until they were delivered to the lab for analysis. Samples that were below detection limits of 36 Ct for SARS-CoV-2 were excluded from statistical analysis.

\section{Sediment Sampling}

On December $9^{\text {th }}$, two sediment samples were taken at an upstream and downstream site from the Middle Fork sampling location to examine for the presence of SARS-CoV-2 and PMMoV. To mimic recreational activities like wading, the sediment was disturbed for 30 seconds and then a grab sample was collected from the stream.

\section{Associated Wastewater Surveillance}

Metropolitan Sewer District and the University of Louisville's Christina Lee Brown Envirome Institute provided data from their wastewater sampling as part of the Co-Immunity Project studying the prevalence and distribution of SARSCoV-2 by surveying for the virus in the wastewater and clinical samples of Jefferson County, Kentucky. 
A 24-hour wastewater composite sample at intervals of every 15 minutes were taken twice weekly since May 2020. These samples were chilled immediately in the field and then taken to the University of Louisville lab for qPCR analysis. The two sites from this associated wastewater sampling, Locust and Lobdell Alley, and Newburg Road, were chosen under the direction of the Envirome Institute so that they were in close proximity to the stream sampling sites and within the same sewershed (Figure 2).

\section{$\underline{\text { Lab Analysis }}$}

Lab analysis consisted first of an RNA extraction using the Zymo Fecal/Soil kit with the Urine Conditioning buffer. Then, three positive and three negative controls were prepared for each sample and run in triplicates. Targets were SARS-CoV-2 nucleocapsid, and PMMoV as an indicator of human fecal input. Finally, the number of copies per $\mathrm{mL}$ were reported based on the standard curve for both PMMoV and SARS-CoV-2 with a detection level of 36 copies of RNA for SARS-CoV-2 (Eurofins, Louisville, Kentucky).

Sediment grab samples were packed with ice packs for preservation and shipped to an external lab (Verily lab, Stanford, California) for analysis of PMMoV and SARS-CoV-2 presence. 


\section{Statistical Analysis}

Statistical software R was used for calculations of comparisons from each

water quality variable to the site and date ( $R$, Ime4, RStudio Version 1.3.1093). A two-way analysis of variance (ANOVA), and then a Tukey's range test was used for each variable (temperature, percent saturation dissolved oxygen, concentration of dissolved oxygen, salinity, SARS-CoV-2 copies per $\mathrm{mL}$, and PMMoV copies per $\mathrm{mL}$ ) to determine significance. Turbidity and $\mathrm{pH}$ were not normally distributed data, thus a Kruskal-Wallis rank sum test, then a pairwise Wilcox test was used to determine significant difference. 


\section{RESULTS}

\section{Geospatial Analysis}

Both forks are primarily residential in nature, however the Middle Fork contains twice the amount of parks and open space as the South Fork (Figure 2). In the Middle Fork watershed of Beargrass Creek, about $80 \%$ of land is developed and $19 \%$ is considered vegetation, while in the South Fork watershed, $88 \%$ of land cover is developed and almost $11 \%$ is vegetation (Table 7 ). In terms of impervious surfaces, the Middle Fork is composed of $24.6 \%$ impervious cover, and the South Fork contains 37.6\% (Table 8). The Middle Fork has nearly twice the vegetation than the South Fork, and $13 \%$ less impervious surface cover.

\section{Water Quality Variables}

Mean temperatures for the Middle and South Forks were significantly different on the first $(p<0.0001)$ and third sampling dates $(p=0.0066)$ where the Middle Fork had a lower temperature on the first sampling date and a higher temperature on the third sampling date than the South Fork. There was no significant difference in temperature between forks on the second sampling date $(p=0.2323)$ (Figure 4).

Mean percent dissolved oxygen (Figure 5) for the Middle Fork was $96.22 \%$ saturation, and $64.34 \%$ saturation for the South Fork for November $12^{\text {th }}$ 
$(p<0.0001)$. On November $24^{\text {th }}$ for the Middle Fork, percent dissolved oxygen was $105.6 \%$, and $77.14 \%$ for the South Fork $(p<0.0001)$. On the last sampling date of December $31^{\text {st }}$, the percent saturation of dissolved oxygen was $96.16 \%$ for the Middle Fork and $90.02 \%$ for the South Fork $(p<0.0001)$.

Concentration of dissolved oxygen (Figure 6) for November $12^{\text {th }}$ for the Middle Fork was $10.27 \mathrm{mg} / \mathrm{L}$, and $6.66 \mathrm{mg} / \mathrm{L}$ for the South Fork $(p<0.0001)$. Concentration of dissolved oxygen for November 24th was $11.67 \mathrm{mg} / \mathrm{L}$ for the Middle Fork and $8.43 \mathrm{mg} / \mathrm{L}$ for the South Fork $(\mathrm{p}<0.0001)$. On December $31^{\text {st }}$, the concentration of dissolved oxygen was $11.27 \mathrm{mg} / \mathrm{L}$ for the Middle Fork and $10.71 \mathrm{mg} / \mathrm{L}$ for the South Fork $(p=0.0013)$.

On November $12^{\text {th }}$, mean turbidity (Figure 7 ) for the Middle Fork was 0.9 NTU, and the South Fork was 3.0 NTU. Mean turbidity for the Middle Fork on November 24th was $1.3 \mathrm{NTU}$, and for the South Fork, the mean was 2 NTU. On the third sampling date, December $31^{\text {st }}$, the Middle Fork mean turbidity was 22.9 NTU, and the South Fork had a mean turbidity of 22.5 NTU. Turbidity was found to be significantly different between the Middle Fork and South Forks $(p=0.046)$.

Mean salinity (Figure 8) on November $12^{\text {th }}$ for the Middle Fork was 0.28 psu and for the South Fork, $0.22 \mathrm{psu}(\mathrm{p}<0.0001)$. For November $24^{\text {th }}$, salinity was 0.32 psu for the Middle Fork and 0.26 psu for the South Fork $(p<0.0001)$. On the third sampling date on December $31^{\text {st }}$, the mean salinity for the Middle Fork was $0.18 \mathrm{psu}$, and 0.15 psu for the South Fork $(p<0.0001)$.

Mean specific conductivity (Figure 9) was $0.565 \mu \mathrm{S} / \mathrm{cm}$ for Middle Fork, and $0.458 \mu \mathrm{S} / \mathrm{cm}$ for South Fork for the first sampling date $(p<0.0001)$. Specific 
conductivity for the Middle Fork for November $24^{\text {th }}$ was $0.644 \mu \mathrm{S} / \mathrm{cm}$ and 0.535 $\mu S / c m$ for the South Fork $(p<0.0001)$. On December $31^{\text {st }}$, mean specific conductivity was $0.366 \mathrm{mS} / \mathrm{cm}$ for the Middle Fork, and $0.304 \mu \mathrm{S} / \mathrm{cm}$ for the South Fork $(p=0019)$.

For the Middle Fork on November $12^{\text {th }}$, the mean $\mathrm{pH}$ (Figure 10) was 7.92 and 7.56 for the South Fork. On November $24^{\text {th }}$, the $\mathrm{pH}$ for the Middle Fork was 8.13 and 7.58 for the South Fork. On the last sampling date, December $31^{\text {st }}$, the mean $\mathrm{pH}$ in the Middle Fork was 7.75 and 7.58 for the South Fork. pH was found to be significantly different between the Middle and South Forks $(p<0.0001)$.

Nutrients taken with Hach test strips were consistent for each date and stream. Nitrate (range of 0-50 mg/L), nitrite (range of 0-3 mg/L), and ammonia (range of 0-6 ppm) were always under the level of detection for each date and stream. Phosphate was $5 \mathrm{ppm}$ (range of $0-50 \mathrm{ppm}$ ) for each date and stream.

\section{SARS-CoV-2 and PMMoV}

None of the 15 samples detected SARS-CoV-2 RNA in the Middle Fork of Beargrass Creek, while one of 15 samples detected SARS-CoV-2 RNA in the South Fork on the first sampling date, November $12^{\text {th }}$ (Figure 11). There was no significant difference in SARS-CoV-2 copies per $\mathrm{ml}$ in any of the three dates (November $12^{\text {th }} p=0.5983$, November $24^{\text {th }} p=1.0$, December $31^{\text {st }} p=1.0$ ).

On this first sampling date, PMMoV for the Middle Fork was 47422 copies per $\mathrm{mL}$, and 89807 copies per $\mathrm{mL}$ for the South Fork $(p=0.0356)$. For November $24^{\text {th }}$, mean PMMoV in the Middle Fork was 51543 copies per $\mathrm{mL}$, and 80654 
copies per $\mathrm{mL}$ for the South Fork $(\mathrm{p}=0.0325)$. On December $31^{\text {st }}$, mean PMMoV was 5212 copies per $\mathrm{mL}$ for the Middle Fork and 1495 copies per $\mathrm{mL}$ for the South Fork $(p>0.05)$.

November $24^{\text {th }}$ and December $31^{\text {st }}$ both had one replicate where PMMoV was below the level of detection, and as a result were excluded from analysis. An additional replicate on December $31^{\text {st }}$ was below the level of detection for SARSCoV-2 which was also excluded. These samples, below the detection limit, were excluded for a total of three replicates from the three sampling dates not entered into statistical software R. The Middle Fork had 12 samples, and the South Fork had a total of 15 samples used in the calculation. All other samples detected PMMoV (Figure 12).

\section{Sediment Samples}

At both the upstream and downstream locations on the Middle Fork of Beargrass Creek, SARS-CoV-2 RNA was not detected from the sediment grab samples, however PMMoV was detected. At the upstream location, 1570152 PMMoV gc/g dry weight was found, and at the downstream location 496094 PMMoV gc/g dry weight was found (Table 3).

\section{Discharge and Overflow Data}

Average stream discharge for the first sampling date was $0.2764 \mathrm{~m}^{3} / \mathrm{s}$ in the Middle Fork and $0.2506 \mathrm{~m}^{3} / \mathrm{s}$ for the South Fork (Figure 13). On the second sampling date, stream discharge was $0.1841 \mathrm{~m}^{3} / \mathrm{s}$ for the Middle Fork and 
$0.2124 \mathrm{~m}^{3} / \mathrm{s}$ for the South Fork. On the last sampling date, December $31^{\mathrm{st}}$, stream discharge was $4.7855 \mathrm{~m}^{3} / \mathrm{s}$ for the Middle Fork and $3.4547 \mathrm{~m}^{3} / \mathrm{s}$ for the South Fork.

The only documented overflow within two stream miles that discharged into either creek was Sewer Manhole ISO21A-SI (Table 4). On October $20^{\text {th }}$, October $29^{\text {th }}$, and December 30th due to heavy rain, ISO21A-SI discharged with a total volume of 200,000 gallons of sewage overflow, $7,500,000$ gallons, and $8,500,000$ gallons, respectively to the receiving stream of Middle Fork of Beargrass Creek. The other CSOs and SSOs (CSO 108, sewer manhole 23211, sewer manhole 30681 , sewer manhole 45835 , and sewer manhole 45900) did not have documented overflows during the time of study.

\section{Associated Wastewater Data}

There was consistent presence of SARS-CoV-2 RNA in the two associated wastewater sampling locations (see Table 5). At the Locust and Lobdell Alley location and the Middle Fork as the receiving stream, there were a large number of copies of SARS-CoV-2 RNA three days before our first sampling event, but no detection of SARS-CoV-2 in the Middle Fork from the stream. SARS-CoV-2 remained present at both Locust and Lobdell Alley, and Newburg Road locations throughout the duration of the stream sampling study. 


\section{DISCUSSIONS AND CONCLUSIONS}

The Middle and South Forks of Beargrass Creek primarily varied in the detection of SARS-CoV-2 on a single sampling date in the South Fork in contrast to the ubiquitous presence of the virus in the nearby wastewater sampling. The two Forks of the stream showed consistent presence of PMMoV, indicating consistent sewer input, on each sampling date. In addition, there was no detection of SARS-CoV-2 from the sediment sample from immediately upstream and downstream of the Middle Fork stream sampling location, however PMMoV was detected here, indicating human waste input.

\section{$\underline{\text { Stream Health and Morphology }}$}

Beargrass Creek has been part of a number of projects that involve channel modification that as a result have increased the stream velocity at shallower depths during low-flow conditions in some areas. For example, in the 1850s, the section of Beargrass Creek that empties into the Ohio River was rerouted to bypass downtown Louisville, and left the empty streambed to become a sewer (MSD 2020a). In one area of the South Fork of Beargrass Creek downstream of this study's sampling site, channel modifications have altered the biota of Beargrass Creek (Ruhl and Jarrett 1999). 
In more recent history, because of these channel modifications impacting the health of the stream, the Army Corps of Engineers and local LouisvilleJefferson County Metropolitan Sewer District announced in 2019 an ecosystem study on the forks of Beargrass Creek. The goal of this ecosystem study is to restore the form and function of the creek from sections of concrete channels to contain more riparian buffers and wetlands (Army Corps of Engineers, 2019; MSD 2020b).

In the Middle Fork, from mile 2.9 to 15.3 of the creek where the sample site was contained, the presence of fecal coliform is thought to be due to illegal waste disposal, sewer overflows, and urban runoff that contributes to the section not supporting primary contact recreation like swimming or wading. However, this section does support aquatic life (Kentucky Water Health Portal 2001, 2009).

In the South Fork, from mile 2.7 to 13.6 , there are suspected similar sources of pollution that cause eutrophication, sewer overflows and the presence of fecal coliform, potentially impacting the turbidity of the stream. This section of the South Fork does not support aquatic life or swimming (Kentucky Water Health Portal 2001, 2009).

The significant differences we found in specific water quality variables could be due to the surrounding residential land use and resulting potential pollution and runoff. Temperature was significantly greater in the South Fork on the first sampling date, and significantly lower than the Middle Fork on the last sampling date, with no significant difference on the second date. The temperature did not exceed $31.7^{\circ} \mathrm{C}$ as guided by the state, however we sampled 
during winter months, and the results are only representative of a single season (EPA 2020d).

Dissolved oxygen (percent saturation and concentration) was higher in the Middle Fork than the South Fork on all three sampling dates. Dissolved oxygen was within the threshold of higher than $5.0 \mathrm{mg} / \mathrm{L}$ for each stream (EPA 2020d). Additionally the concentration of dissolved oxygen $(\mathrm{mg} / \mathrm{L})$ for the Middle Fork was higher than the South Fork on each sampling date.

Turbidity in the South Fork was significantly different than in the Middle Fork between the three sampling dates, with a higher value on the higher discharge sampling date. The state of Kentucky dictates that total suspended solids and total settleable solids cannot change in amount that it impacts the aquatic community adversely (EPA 2020d). The Middle Fork where the stream sampling location is supports aquatic life, however the South Fork does not (Kentucky Water Health Portal 2001, 2009).

Similarly total dissolved solids or specific conductance for the state of Kentucky cannot change in concentration such that the aquatic community is harmed (EPA 2020d). Salinity and specific conductance were significantly higher in the Middle Fork than in the South Fork for each variable on each sampling date, however there may be other variables that contribute more weight to the overall health of the stream, specifically dissolved oxygen and the presence of fecal coliform (Said et al. 2004). 
The two forks were found to be significantly different in $\mathrm{pH}$ values between dates. Despite those differences however, the values detected were still within the range of $\mathrm{pH} 6$ and $\mathrm{pH} 9$ for the requirements of the state of Kentucky surface water standards, but we did not measure the change in $\mathrm{pH}$ over time, which is another indicator of water quality health. Changes in $\mathrm{pH}$ of more than $1.0 \mathrm{pH}$ unit over a 24-hour period are not supportive of aquatic life (EPA 2020d).

Nitrogen concentrations from the Middle and South Forks are consistent with concentrations determined by a study in Canada on total nutrient and phosphorus concentrations suitable for aquatic biological activity in streams over varying watershed characteristics. The suitable range for biological activity in the streams in Canada for total nitrogen was 0.02 to $0.06 \mathrm{mg} / \mathrm{L}$ (Chambers et al. 2012), and in the present study, nitrogen was not detected. For total phosphorus, the range determined by the study in Canada was 0.59 to $2.83 \mathrm{mg} / \mathrm{L}$ (Chambers et al. 2012). The values in Beargrass Creek were at $5 \mathrm{mg} / \mathrm{L}$ on each sampling date. The degree of precision from the Hach test strips may not be a high enough resolution for further interpretation though results indicate total phosphorus concentrations may be higher than is suitable for aquatic activity.

Ammonia remained below the level of detection on each sampling date for both Forks, which is within Kentucky's requirements for un-ionized ammonia of staying under $0.05 \mathrm{mg} / \mathrm{L}$ (EPA 2020d), however the resolution of the Hach test strips may impact whether the actual amount of ammonia was within the requirements. 
SARS-CoV-2 was detected in the South Fork, and the not the Middle Fork, as well as significantly higher PMMoV values for the South Fork over the Middle Fork on the two first sampling dates could have been in part driven by the disparity in stream health. The lower values of detected of PMMoV on the last sampling date in both streams, as well as the corresponding higher turbidity levels, are likely due to the sampling being on the rising limb of a rain event with a higher discharge than the previous two rain events and sampling dates. The higher stream discharge may have diluted or flushed evidence of PMMoV downstream.

There were significant differences between the Middle and South Forks of Beargrass Creek, most notably shown in dissolved oxygen, salinity, specific conductivity, salinity, and $\mathrm{pH}$ that could be due to the Middle Fork having a healthier history of less channel modification than the South Fork had. The difference in overall stream health from the Middle Fork versus the South Fork could be happening synergistically with the surrounding land use, which contributes or mitigates the amount of stormwater, and then the probability of overflows, which lead to pollution in the stream.

\section{Watershed}

Land use may influence differences in water quality parameters between the streams, specifically the amount of parks and open spaces (Table 2). There are double the amount of parks and open spaces in the Middle Fork than the South Fork, which can contribute to the percentage of impervious surfaces in that 
watershed, and consequently in the amount of stormwater that overwhelms the sewer system and the potential for overflows.

The section of the Middle Fork watershed that drains to the USGS monitoring station 3293000 near our sample location is about 18.9 square miles and considered 76\% urban (MSD 2016a). Likewise, the area of the South Fork that drains to the USGS monitoring location near our sample site is approximately 17.2 square miles and $85 \%$ urban (MSD 2016a). The increase in percentage of urban area in the South Fork, and the increase in percentage of parks and open spaces in the Middle Fork could have had an impact on the differences in water quality variables between the Forks.

Land use practices from residential yards, impervious roofs, roads, and parking lots can contribute to the amount of stormwater runoff. This discrepancy in land use contributing to runoff might explain why there was an increased presence of PMMoV in the South Fork on the first and second sampling dates where there was a moderate level of stream discharge. The third sampling date was immediately following a much larger rain event and could have diluted or flushed the presence of PMMoV.

The sediment samples, although a low N, support the comparison of the presence of SARS-CoV-2 RNA in the wastewater, but the lack of it in the stream. It also further enforces the problematic presence of PMMoV, indicating that although this study did not find strong evidence of SARS-CoV-2, it still found evidence of human waste in the streams. 


\section{Sewer System}

The dates, times, volume, and location of the documented overflows could play a role in the amount of SARS-CoV-2 and PMMoV detected. The documented CSO/SSO discharges were closest to the last sampling date, within 24 hours of the time of collection, at the Middle Fork site. Despite there not being a documented sewer overflow within five stream miles in the South Fork on the last sampling date, PMMoV was still detected. The amount of rainfall, indicated by the stream discharge (Figure 13), preceding the last sampling date could have diluted the existing PMMoV and could have contributed to the fact that detected PMMoV was an order of magnitude less than the amount detected on November $24^{\text {th }}$. This sampling date was immediately after a much heavier rain event than the previous two, which may have contributed to there not being a significant difference in PMMoV detected between streams.

The presence of PMMoV was significantly lower in the Middle Fork than in the South Fork on the first two sampling dates while the third date was had no significant difference in PMMoV between streams. There were however, more documented sewer discharges in the South Fork than the Middle Fork over our collection period which may suggest that there are alternative sources of untreated wastewater entering the stream such as broken pipes or interceptor sewers with exfiltration issues (Loren Levitz, personal communication, March, 26, 2021). Potential alternative point-source pollutions could be private sewer systems that are not associated with MSD. Within five miles of the South Fork stream sampling location, there is a privately owned property sewer system 
outside of the city's treatment. On the Middle Fork there is a much smaller privately owned sewer system that is about one kilometer from the stream and about two kilometers from the sample location (LOJIC Online 2020).

There are specific CSO and SSO details that could have impacted the amount of discharge that actually reached the stream. Situated on the Middle Fork of Beargrass Creek, sewer Manhole 45900 catches mainly residential input at around 6,400 acres of its catchment area, second is industrial and commercial at about 550 acres. The area immediately surrounding this manhole is characterized by a semi-pervious parking lot which may diminish the potential overflow into the creek due to the small amounts of vegetation growing in the pattern of the parking lot which may hinder the sewage from reaching the stream (MSD 2010a). Sewer Manhole ISO21A-SI similarly catches just over 6,000 acres of residential area, and about 550 acres of commercial or industrial land use (MSD 2010b). Sewer Manhole 08935-SM catchment area drains about 5,600 acres of residential land, and more than 450 acres of commercial and industrial land use (MSD 2010c).

On the South Fork of Beargrass Creek, combined sewer CSO 108 drains from a population of around 4,000 people, chiefly residential, with approximately $39 \%$ of its catchment areas as impervious surface (MSD 2013). Sanitary sewer 51594 has a catchment area of only 4 acres, and it is all residential. This SSO, although a small area, has overflowed frequently in its past. From the years 2011 to 2015, it overflowed an average of 61.4 times (MSD 2010d). Sanitary sewer 23211 drains from around 6,000 acres of residential land use, and about 500 
acres of commercial and industrial land use. From the years 2011 to 2015, this manhole overflowed an average of 31.5 times (MSD 2010e).

Sewer Manhole 18654 overflowed on October $29^{\text {th }}, 2020$ with a total volume of 35,025 gallons of sewage due to heavy rain, which could have had an impact on our first sampling date (MSD 2016b). An overflow two weeks prior to our sampling, however, is unlikely to impact our detection of SARS-CoV-2 because of the evidence that suggests that the virus RNA only survives two days in tap water at room temperature (Bivins et al. 2020). Other research suggests that in river water, SARS-CoV-2 RNA is persistent up to 5.2 days in non-filter sterilized river water at $20^{\circ} \mathrm{C}$ and is stable over the course of 20 days (SalaComorera et al. 2021).

The Middle Fork of Beargrass Creek has fewer sewer overflow locations than the South Fork within two stream miles which could have contributed to the higher likelihood of the presence of SARS-CoV-2 in the South Fork than in the Middle Fork given the sample locations. Two or three stream miles past the twomile cutoff from our sample site on the Middle Fork of Beargrass Creek (MSD 2021a), there is a cluster of sanitary sewer overflows. Similarly, on the South Fork of Beargrass Creek, there is a cluster of sanitary sewer overflows on a tributary of the creek, which could impact the level of detection of SARS-CoV-2 in the stream, but was not specifically studied in this experiment. 


\section{$\underline{\text { Vegetation Cover, Sanitation, and Socioeconomic Status }}$}

Untreated sewage and insufficient access to adequate sanitation are typically issues associated disproportionately with the Global South. A study on 15 cities in the Global South including Mumbai, India, Kampala, Uganda, and Bengaluru, India indicated that $62 \%$ of sewage is disposed of inadequately. The disposal of sewage led to pollution of streams, rivers, farms, and low-elevation areas. Exposure to pathogens, development of disease and caretaking for ill family members, and increase in healthcare costs are some of the consequences of lack of access to sufficient sanitation (Satterthwaite et al. 2019).

Moreover, even in the United States there are still instances of low sanitation. A study estimating people in the urban United States without basic water or basic sanitation from 2017 to 2019 determined that $0.24 \%$ lacked basic water access which is equal to 610,000 people. Additionally, they determined that $0.37 \%$ of people in the urban United States lacked basic sanitation, equal to 930,000 people from 2017 to 2019 (Capone et al. 2020). Despite the low overall percentage of persons without access to basic sanitation in the United States, these individuals are still at risk for exposure to pathogens and the spread of disease due to insufficient hygiene.

Beyond access to sanitation, these areas of lower socioeconomic status, and non-white demographics, have also been shown to be correlated with decreased access to green spaces and a smaller percentage of tree canopy compared to their wealthier and white counterparts (Gee and Payne-Sturges 2004; Kolosna and Spurlock 2019). Although the urban tree canopy can be 
irregular across geographic regions, and even within cities, there is evidence a portion of the variance in canopy cover associated with race and socioeconomic originates from historically unjust practices such as residential segregation, and the disproportionate allocation of resources including plantings of vegetation. Utilizing percent urban tree canopy cover is a potential way to measure environmental equity given the context of these persistent racially and socioeconomically driven practices (Kolosna and Spurlock 2019).

Furthermore, considering the relationship between vegetation and its role in mitigating stormwater runoff in minimizing sewer overflows (Booth 2005) and areas with a lower percentage of urban tree canopy and its correlation with lower socioeconomic status (Gee and Payne-Sturges 2004; Kolosna and Spurlock 2019) can help provide context for the differences between the Middle and South Fork watersheds of Beargrass Creek. The relationship between tree canopy coverage and other vegetation with areas of higher income, and the presence of waste in water bodies of areas of lower socioeconomic status bears further investigation.

These substantial differences where the Middle Fork has nearly twice the vegetation than the South Fork, and $13 \%$ less impervious surface cover, and the Middle Fork containing $8 \%$ less developed land cover than the South Fork may help explain a portion of the differences in water quality we found in the streams, and why there was more PMMoV detected in the South Fork. With less vegetation and more impervious land cover in the South Fork watershed, there is 
likely more stormwater runoff can contribute to sewer overflows, or carry more pollutants across the ground in the form of runoff.

The amount of untreated sewage in the both watersheds, as indicated by the evidence of PMMoV, also occurred in a relatively high income area. The median household income of Jefferson County from 2015 to 2019 is $\$ 56,586$ and the median household income for the United States is $\$ 62,843$ (United States Census Bureau 2019). This evidence highlights that even in high income areas, issues of human waste traveling to bodies of water can still occur.

\section{Associated Wastewater Surveillance}

Simultaneously during this stream study, MSD and the University of Louisville Envirome Institute conducted wastewater surveillance to detect the presence of SARS-CoV-2 to better inform and understand the distribution of the virus in Jefferson County, Kentucky. The wastewater surveillance has been critical for Jefferson County to predict the distribution and transmission of the virus and the resulting presence of COVID-19 (Holm, 2021). An important comparison of this wastewater surveillance to the nearby streams of Beargrass Creek receiving sewer overflow input was that there was clear and consistent presence of SARS-CoV-2 in the wastewater that contributed to the CSOs and SSOs of this study, but not in the stream.

PMMoV may also be much more stable (Kitajima et al. 2018) than SARSCoV-2, which could have impacted the low detection of SARS-CoV-2 and much more consistent detection of PMMoV even on milder rain events, and few 
documented overflows. In a study done in three rivers in Colorado, US, PMMoV showed very little reduction from the outfall source of wastewater to the downstream sampling locations, indicating the persistence of the virus (Sassi et al. 2018) .

\section{Similar Studies}

The limited publications on surface waters and the presence of SARSCoV-2 RNA, namely Japan, Italy, and Ecuador (Haramoto et al.; Rimoldi et al.; Guerrero-Latorre et al. 2020), also sampled in wastewater near their river or stream samples. Although this particular study did not sample directly from sewer lines, it was done with the knowledge of a similar parallel study in Jefferson County on wastewater and community infection rates (Yaeger et al. 2020; Smith 2021).

Another study conducted in Louisville, Kentucky (Day and Seay 2020) analyzed a specific SSO that is a pollution source for the South Fork of Beargrass Creek. SSO 16649 is upstream of our sampling location, however it is further away from the stream than we selected for our buffer. This study looked at a longer period of time than this stream sampling study, over the course of two years and received the documentation of 20 overflows from MSD on SSO 16649. A critical component of the study by was incorporating rainfall data to better understand the relationship between rain event duration and intensity and whether an overflow occurred (Day and Seay 2020). 
After analyzing the 42 storm events that occurred over their study area, they found that overflows often happened when the storm event overlapped with peak period of sewer flow (morning and evening) and where the storm's intensity also fell during this period. Overflow events from this study also slanted towards storms where the most intense period of rainfall happened during the first half of the storm event. A commonality in the overflow events that Day and Seay found was that the timing and intensity of the rain with peak sewer flow influenced whether an overflow event occurred (Day and Seay 2020).

In this case, the timing, and timing of intensity, of the rain events in this stream sampling study may have been a factor in the low number of overflow events near our sampling area, which could have resulted in the lack of detection of SARS-CoV-2 virus. However, there was still detection of PMMoV which suggests that there may be alternative sources of human fecal input on a consistent basis.

The study on the presence of SARS-CoV-2 in Japan did not find SARSCoV-2 in any of the three river water samples collected on March $17^{\text {th }}$ and May $7^{\text {th }}, 2020$. They used four qPCR tests and two nested PCR assays, electronegative membrane-vortex (EMV) method and membrane adsorptiondirect RNA extraction method. This study also used pepper mild mottle virus as an indicator of human waste input, similar to this study's use of PMMoV, however their threshold of detection was $39.96 \mathrm{Cp}$ and this study's was $36 \mathrm{Cp}$ (Haramoto et al. 2020). 
This study from Japan was over the summer of 2020 with a total of three river grab samples and ten wastewater samples from a suburb of Tokyo, Yamanashi Perfecture. SARS-CoV-2 was only detected in one secondary treated wastewater sample. The study in Japan an even smaller sample size than this study in terms of stream samples. One note is that the low prevalence of COVID19 infections in their study area could have impacted the lack of detection of the virus (Haramoto et al. 2020).

In Italy, three river samples were taken from Milano Metropolitan Area surveying for SARS-CoV-2 via RT-PCR and infectivity using VERO E6 cells, heat-inactivated fetal bovine serum and Penicillin-Streptomycin. The limit of detection range was $1 \times 10^{1}-1 \times 10^{-2} \mathrm{TCID}_{50}$. In each of the three river samples, SARS-CoV-2 was detected on April $14^{\text {th }}, 2020$, but only one of the rivers showed positive detection of the virus on April $22^{\text {nd }}, 2020$. Using caffeine as an indicator of human waste input into the rivers, there was evidence that the caffeine concentrations were higher than the background levels typical of a drought period, 0.3-0.4 $\mu \mathrm{g} / \mathrm{L}$ versus 0.08-0.09 $\mu \mathrm{g} / \mathrm{L}$ (Rimoldi et al. 2020).

There was evidence of SARS-COV-2 in raw wastewater but not treated wastewater. Their findings also determined that treatment of the wastewater eliminates $99 \%$ of caffeine from the discharges into the rivers, yet the river samples still contained higher levels caffeine. This discrepancy suggests that there is another source of untreated wastewater input into the rivers, potentially from combined sewer overflows, similar to the input to Beargrass Creek. In addition, the wastewater and river samples were instantaneous grab samples, 
timed nearly simultaneously, rather than composite samples like in the associated wastewater sites from Jefferson County in the present study (Rimoldi et al. 2020).

Similarly to the Beargrass Creek study, there was consistent evidence of direct human waste input using the PMMoV virus, caffeine in the case of the study in Italy (Rimoldi et al. 2020). However, the amount of wastewater discharge into the rivers of study in Italy could have been different depending on local rainfall amounts, percentage of impervious surfaces, and the surrounding land use that could contribute to urban runoff in Italy versus the conditions around Beargrass Creek. These potential differences could have contributed to higher detections of the SARS-CoV-2 virus in the rivers in Italy than in this study. The rivers in the study in Italy were sampled from bridges, rather than from the stream banks of Beargrass Creek.

Infectivity for the river samples in Italy were null despite there being positive RNA detection (Rimoldi et al. 2020). In the samples from Beargrass Creek, there was no analysis of infectivity, only the presence of the RNA. Because the infectivity was null from the three rivers in Italy, it suggests that transmission of the virus from a surface water source is unlikely, but research in this area is still new (Rimoldi et al. 2020).

Three locations in Quito, Ecuador were sampled in June of 2020 for SARS-CoV-2 using the skimmed milk flocculation method and qRT-PCR, and Human Adenovirus as an indicator of human input. This study in Ecuador found evidence of strong human waste input from their detections of Human 
Adenovirus, and in all three locations found SARS-CoV-2 N nucleocapsid gene. The viability of virus was not measured, however (Guerrero-Latorre et al. 2020).

Ecuador only treats about $20 \%$ of its sewage which may lead to more contaminated rivers than the US might have, including Beargrass Creek. The rivers of Quito are characterized by large percentage of untreated wastewater directly discharged into them, as the city only treats three percent of the sewage. As a result, the rivers sampled have very high amounts of organic and inorganic contamination (Guerrero-Latorre et al. 2020). Although there was consistent evidence of PMMoV in the samples taken from Beargrass Creek, had there been more direct input like in Ecuador, more SARS-CoV-2 RNA may have been detected in the Middle Fork and South Forks.

\section{Limitations}

Despite the results identifying the presence of SARS-CoV-2 and PMMoV in streams receiving sewer overflow input, there are a number of limitations to consider. The cost per sample, approximately $\$ 300$, was a financial constraint, and a total of 30 replicates was the maximum number of permissible samples. Furthermore, the sampling schedule was designed around the small number of replicates, but there are a number of different sampling regimes that would be appropriate for this research including sampling during or immediately after rain events at specified intervals, sampling over a longer period of study, and sampling in transects downstream to examine different outfall locations and the potential travel of the virus. Extending the length of study may also allow for 
higher resolution result due to a larger sampling of rain events, and sampling dates. Lab hours, weekends, and holidays also constrained the sampling cadence.

Exploring specific CSOs and SSOs that have a frequent history of overflowing is an additional area to direct further stream sampling to better understand the relationship between the presence of SARS-CoV-2 in the sewer system, and the lack of it in the stream sampling we found. The sewer overflow data, due to its quarterly nature, inherently lags beyond the overflow events themselves. Obtaining this data in a more real-time fashion could help refine where and when to sample from streams.

Higher resolution of nutrient data would aid in better understanding the connections between eutrophication, stream water quality, and the presence of PMMoV or SARS-CoV-2 viruses. In addition, further exploration of watershed characteristics including more hydrologic mapping based on impervious surfaces and tree canopy or vegetation cover may also assist in these interpretations.

\section{Future Research and Recommendations}

\section{Wastewater Based Epidemiology and Beyond}

Better understanding the relationship between the occurrence of SARSCoV-2 in the sewer system, but not finding in surface waters, or the sediment, that receive those periodic inputs is an area of further research. Timing and intensity of rain events, volume of CSO or SSO discharge, and the conditions of 
the stream may all be considerations to factor when doing further research in this area as they all may affect the stability of SARS-CoV-2.

The lack of SARS-CoV-2 RNA in the sediment despite there being a significant presence of human fecal input as indicated by PMMoV lends to future research questions such as what kinds of particles or sediments SARS-CoV-2 might adhere to more than others (Mohapatra et al. 2020). Because the virus is positively charged, sediment compounds that are negatively charged may be one area of focus (Bitton 1974).

In addition, because of its highly adhesive properties, clay has been shown to attach to the spikes on the SARS-CoV-2 virus in molecular simulations (Abduljauwad et al. 2020). For this reason stream sediments with large amounts of clay could harbor more of the virus due to its affinity for clay particles. Surrounding conditions like salinity, and $\mathrm{pH}$ may also impact these interactions (Bitton 1974), and could therefore impact the amount of SARS-CoV-2 RNA detected if more adhered to the sediment, or if it was transported with the stream load.

Over the study period there were a number of overflows that occurred where the receiving stream was Chenoweth Run which is a tributary of Floyd's Fork, a watershed immediately southeast of the Beargrass Creek watershed and approximately 10 kilometers away. This may be another area of focus for future work as it received many sanitary sewer overflows, and a number of combined sewer overflows (LOJIC Online 2020; MSD 2021b; MSD 2021c). 
In cases where communities have low sanitation, or those not connected to a sanitary sewer system, surveying surfaces waters may provide an alternative to sampling wastewater as an early warning system for SARS-CoV-2 in a similar manner that wastewater based epidemiology offers. Rivers that regularly receive these sewage discharges may be able to provide this surveillance (AguiarOlivera et al. 2020).

\section{Stormwater and CSO/SSO Discharge Mitigation Recommendations}

An ongoing issue impacting stream quality is discharges from sewers. Mitigation of these overflows often revolves around stormwater reduction and green infrastructure, reducing the possibility of human waste entering bodies of water in the environment and presenting risk of transmission from contact with these waters. The viability of the virus in the environment is a less-known and important area for future research to understand if there is potential for infection of the virus from primary contact with river or stream water when the virus enters the body of water from these point-source pollutions (Mohapatra et al. 2020).

Because stormwater is a large contributor to combined inputs into sewers, and subsequent overflows, mitigation of the stormwater can help reduce the number of sewage overflows. Specific solutions such as rain gardens, increasing the riparian zones of streams, and incorporating political, social, and economic management practices can help ensure a more sustainable outcome. Land use, 
and cultural and social decisions can impact the ecological environment (Autixier et al. 2014; Dosskey et al. 2010; Grimm et al. 2005).

Enhancement of riparian zones and the surrounding watershed may provide some relief and buffer to streams. There are both short-term and longterm solutions that can improve water quality and reduce stream pollution like riparian plantings and fencing versus tasks such as land use management of the wider watershed or creating conditions where stormwater can percolate through the soil on a larger scale (Booth 2005). It is also worth noting that the degree of degradation will likely influence the amount of time lag it takes for restoration to reestablish healthy processes of the ecosystem (Dosskey et al. 2010). Knowing that the Beargrass Creek has experienced many modifications stresses the importance of restoration of the watershed.

Rain gardens could be a mitigation method for reducing the amount of stormwater runoff that could combine with the sewer system and induce CSOs or SSOs. Rain gardens may be most effective at reducing runoff during smaller rain events however (Li et al. 2019). Combining rain gardens with more substantial mitigation practices, like reducing the percentage of impervious surfaces may alleviate the stormwater volume for those rain events that pose a greater risk to inducing a combined sewer or sanitary sewer overflow (Autixier et al. 2014).

Rain barrels are another small-scale solution to reducing roof runoff from individual homes. Although the benefits could be variable based on different climate zones across the United States, rain barrels can provide additional incentives for homeowners to implement their use for irrigation and gardening 
purposes. Areas like the southwestern United States, based on simulations of daily precipitation records, would benefit more than the southeastern United States (Litofsky and Jennings 2014). Pairing rain barrels with other methods of stormwater reduction to better mitigate roof runoff may be a solution in regions where rain barrels have less of an impact on alleviating stormwater.

In addition to increasing green infrastructure solutions, bolstering the existing gray infrastructure may be a complimentary tool. Building storage basins to contain large influxes of sewage flow and rainwater to reduce overflows is one method. Optimizing the timing of the incoming sewage and rate of treatment at wastewater treatment plants may also alleviate potential combined and sanitary overflows. Lastly, regular maintenance and pollution prevention from municipal sewer companies is another way to ensure the optimum sewer system operation (Tavakol-Davani et al. 2015).

In conclusion, integrating both green and gray infrastructure, in a multidisciplinary approach may provide the most sustainable option of mitigating the amount of stormwater and urban runoff that enter the sewer system, and also entering the streams. Making changes and retrofitting existing gray infrastructure to reduce ecological stress (Sun et al. 2020) will require cooperation of many stakeholders including sewer companies, government, and local citizens. Sustainable solutions to solve interdisciplinary issues require interdisciplinary actions. The stormwater issues combining with the sewer system can be mitigated through these integrations and advancements, however there is still research to be done on the impact of the stormwater, how it may carry the 
SARS-CoV-2 virus into nearby streams, and the viability of the virus once it has entered the surface water system. 


\section{TABLES}

\section{Table 1. Existing literature on the presence of SARS-CoV-2 in surface water.}

\begin{tabular}{|c|c|c|}
\hline Study & Site & Results \\
\hline $\begin{array}{l}\text { Rimoldi et al. } \\
2020\end{array}$ & $\begin{array}{l}\text { Treated and untreated wastewater from } \\
\text { treatment plants in Provinces of Milano and } \\
\text { Monza e Brianza and their receiving rivers, } \\
\text { Vettabbia Canal and Lambro Meridionale } \\
\text { River in Italy }\end{array}$ & $\begin{array}{l}\text { SARS-CoV-2 detected, but not quantified, in raw } \\
\text { wastewater samples. SARS-CoV-2 not detected in treated } \\
\text { wastewater grab samples. SARS-CoV-2 RNA was detected } \\
\text { in three different rivers on April 14th and in one river on } \\
\text { April 22nd, but not quantified. Infectivity was null. }\end{array}$ \\
\hline $\begin{array}{l}\text { Haramoto et al. } \\
2020\end{array}$ & $\begin{array}{l}\text { Treated and untreated wastewater and } \\
\text { urban rivers in Yamanashi Prefecture, Japan }\end{array}$ & $\begin{array}{l}10 \text { wastewater samples, influent and secondary treated, } \\
\text { SARS-CoV-2 detected in only one secondary treated } \\
\text { wastewater sample; cumulative cases of COVID-19 was } \\
36 \text { on day of detection of SARS-CoV-2 virus in wastewater; } \\
\text { in river grab samples }(n=3) \text { from May 2020, SARS-CoV-2 } \\
\text { RNA not detected. }\end{array}$ \\
\hline $\begin{array}{l}\text { Guerrero-Latorre } \\
\text { et al. } 2020\end{array}$ & $\begin{array}{l}\text { Three locations of urban rivers in Quito, } \\
\text { Ecuador }\end{array}$ & $\begin{array}{l}\text { Three river locations sampled in June during peak COVID- } \\
19 \text { infection rates; all } 3 \text { samples detected SARS-CoV-2 } \\
\text { RNA ranging from } 2.84 \times 10^{\wedge} 8 \text { copies/ml to } 3.19 \times 10^{\wedge} 9 \\
\text { copies/ml; study area characterized by large amounts of } \\
\text { direct untreated wastewater discharge in rivers; infectivity } \\
\text { was not examined. }\end{array}$ \\
\hline $\begin{array}{l}\text { La Rosa et al. } \\
2020\end{array}$ & $\begin{array}{l}\text { Review to summarize persistence of } \\
\text { coronaviruses (CoV) in water environments } \\
\text { and virus recovery from water environments }\end{array}$ & $\begin{array}{l}\text { Coronaviruses have low stability in the environment and } \\
\text { are highly susceptible to disinfection; higher temperature } \\
\text { is important in the inactivation of the virus as well as } \\
\text { oxidants such as chlorine for the inactivation of non- } \\
\text { enveloped viruses. }\end{array}$ \\
\hline $\begin{array}{l}\text { Sala-Comorera et } \\
\text { al. } 2021\end{array}$ & $\begin{array}{l}\text { River water from Grand Canal in Dublin, and } \\
\text { seawater from Dublin Bay; tested for } \\
\text { infectiousness in sterilized river and } \\
\text { seawater and RNA persistence in non- } \\
\text { sterilized river and seawater at } 4 \text { degrees C } \\
\text { and } 20 \text { degrees C }\end{array}$ & $\begin{array}{l}\text { Infectivity of SARS-CoV-2 starts decay faster in seawater } \\
\text { than river water at } 20 \text { degrees C ( } 4 \text { hours versus } 24 \text { hours); } \\
\text { T (90) of infectious SARS-CoV- } 2 \text { at } 4 \text { degrees C in river } \\
\text { water was } 3.8 \text { days, and in seawater for } 2.2 \text { days; at } 20 \\
\text { degrees Celsius T (90) of infectious SARS-CoV- } 2 \text { was } 2.3 \\
\text { days in river water and } 1.1 \text { days in seawater. RNA was } \\
\text { stable for } 20 \text { days in sterilized river and seawater at both } \\
4 \text { and } 20 \text { degrees C; in filtered river water, SARS-CoV-2 } \\
\text { RNA was stable after } 5.2 \text { days at } 4 \text { degrees C and } 8.9 \text { days } \\
\text { in filtered seaswater at } 4 \text { degrees C; presence of } \\
\text { microbiota increases rate of decay of SARS-CoV-2 RNA at } \\
20 \text { degrees C. }\end{array}$ \\
\hline
\end{tabular}


Table 2. Land use of the Middle and South Forks of Beargrass Creek.

\begin{tabular}{|c|c|c|}
\hline Land Use & $\begin{array}{c}\text { Percent Cover Middle } \\
\text { Fork }\end{array}$ & $\begin{array}{c}\text { Percent Cover South } \\
\text { Fork }\end{array}$ \\
\hline $\begin{array}{c}\text { Single Family } \\
\text { Residential }\end{array}$ & 39 & 39 \\
\hline Right-of-way & 18 & 20 \\
\hline $\begin{array}{c}\text { Parks and Open } \\
\text { Space }\end{array}$ & 13 & 6 \\
\hline Commercial & 10 & 11 \\
\hline $\begin{array}{c}\text { Multi-family } \\
\text { Residential }\end{array}$ & 7 & 6 \\
\hline $\begin{array}{c}\text { Public and Semi- } \\
\text { Public }\end{array}$ & 7 & 10 \\
\hline Farmland & 2 & 5 \\
\hline Industry & 2 & 2 \\
\hline Vacant & 2 & 2 \\
\hline
\end{tabular}

Table 3. Mean temperature (degrees Celsius) for the Middle and South Forks of Beargrass Creek.

\begin{tabular}{|r|r|l|r|}
\hline Date & Mean Temperature (degrees C) & Stream & $p$-value (alpha = 0.05) \\
\hline $11 / 12 / 20$ & 12.07 & Middle Fork & 0.0000001 \\
\hline $11 / 12 / 20$ & 13.47 & South Fork & \\
\hline $11 / 24 / 20$ & 10.77 & Middle Fork & 0.08 \\
\hline $11 / 24 / 20$ & 11.18 & South Fork & \\
\hline $12 / 31 / 20$ & 8.27 & Middle Fork & 0.0381 \\
\hline $12 / 31 / 20$ & 7.7 & South Fork & \\
\hline
\end{tabular}

Table 4. Results of sediment samples on the Middle Fork of Beargrass Creek. Upstream and downstream locations are approximately 300 meters from surface water sample site.

\begin{tabular}{|l|l|l|}
\hline Sample & $\begin{array}{l}\text { SARS-CoV-2 N Gene gc/g dry } \\
\text { weight }\end{array}$ & $\begin{array}{l}\text { PMMoV gc/g dry } \\
\text { weight }\end{array}$ \\
\hline upstream & ND & 1570151.8 \\
\hline downstream & ND & 496093.7 \\
\hline
\end{tabular}


Table 5. Combined sewer overflow and sanitary sewer overflows within five upstream miles of each stream sampling site and their overflow information over the time period of study.

\begin{tabular}{|c|c|c|c|c|}
\hline Date & Stream & Overflow Type & Location & Discharge (gallons) \\
\hline N/A & Middle Fork & SSO & 45900 & 0 \\
\hline N/A & South Fork & CSO & 108 & 0 \\
\hline N/A & South Fork & SSO & 51594 & 0 \\
\hline N/A & South Fork & SSO & 23211 & 0 \\
\hline N/A & South Fork & SSO & 30681 & 0 \\
\hline $10 / 20 / 20$ & Middle Fork & SSO & ISO21A-SI & 200,000 \\
\hline $10 / 29 / 20$ & Middle Fork & SSO & ISO21A-SI & $7,500,000$ \\
\hline $10 / 29 / 20$ & South Fork & SSO & 18654 & 35,025 \\
\hline $12 / 30 / 20$ & Middle Fork & SSO & ISO21A-SI & $8,500,000$ \\
\hline $12 / 31 / 20$ & Middle Fork & SSO & 08935-SM & $2,487,000$ \\
\hline
\end{tabular}

Table 6. Wastewater data from associated surveillance study at associated sampling locations detecting SARS-CoV-2 RNA, corrected by PMMoV copies per $\mathrm{ml}$.

\begin{tabular}{|c|c|c|c|c|c|c|c|c|c|c|c|c|c|}
\hline \multicolumn{14}{|c|}{ SARS-CoV-2 RNA copies/ml/PMMoV } \\
\hline Location & $\begin{array}{l}\text { Receiving } \\
\text { Stream }\end{array}$ & $11 / 9 / 20$ & $11 / 12 / 20$ & $11 / 16 / 20$ & $11 / 18 / 20$ & $11 / 24 / 20$ & $12 / 1 / 20$ & $12 / 3 / 20$ & $12 / 8 / 20$ & $12 / 10 / 20$ & $12 / 15 / 20$ & $12 / 17 / 20$ & $1 / 4 / 21$ \\
\hline Locust \& Lobdell & Middle Fork & 380 & 68 & 269 & 46 & 3 & 186 & 2603 & 12 & 11 & 81 & 4 & 87 \\
\hline Newburg Rd & South Fork & 98 & 67 & 89 & 26 & 11 & 82 & 44 & 11 & 26 & 17 & 9 & 68 \\
\hline
\end{tabular}


Table 7. National Land Cover Dataset (NLCD) land use percentages from 2016 in the Middle and South Fork Watersheds of Beargrass Creek.

\begin{tabular}{|c|c|c|}
\hline Land Cover Type & Middle Fork Watershed & South Fork Watershed \\
\hline \multicolumn{3}{|c|}{ DEVELOPED } \\
\hline Developed High Intensity & $5.48 \%$ & $11.46 \%$ \\
\hline Developed Low Intensity & $27.65 \%$ & $32.43 \%$ \\
\hline Developed Medium Intensi & $12.51 \%$ & $22.21 \%$ \\
\hline Developed Open Space & $34.80 \%$ & $22.65 \%$ \\
\hline Total & $80.45 \%$ & $88.73 \%$ \\
\hline \multicolumn{3}{|c|}{ VEGETATION } \\
\hline Cultivated Crops & $1.48 \%$ & $0.46 \%$ \\
\hline Deciduous Forest & $4.81 \%$ & $2.90 \%$ \\
\hline Emergent Herbaceous We & $0.03 \%$ & $0.00 \%$ \\
\hline Evergreen Forest & $0.66 \%$ & $0.21 \%$ \\
\hline Grassland/Herbaceous & $0.11 \%$ & $0.05 \%$ \\
\hline Mixed Forest & $10.37 \%$ & $6.21 \%$ \\
\hline Pasture/Hay & $1.64 \%$ & $1.07 \%$ \\
\hline Shrub/Scrub & $0.00 \%$ & $0.00 \%$ \\
\hline Total & $19.09 \%$ & $10.90 \%$ \\
\hline \multicolumn{3}{|c|}{ OTHER } \\
\hline Barren Land & $0.24 \%$ & $0.17 \%$ \\
\hline Open Water & $0.22 \%$ & $0.05 \%$ \\
\hline Total & $0.46 \%$ & $0.22 \%$ \\
\hline
\end{tabular}

Table 8. NLCD Impervious Surface Cover in Middle and South Fork Watersheds of Beargrass Creek.

\begin{tabular}{|l|r|r|}
\hline \multicolumn{1}{|c|}{ Watershed } & $\begin{array}{c}\text { Area of Impervious } \\
\text { Surface (square meters) }\end{array}$ & $\begin{array}{c}\text { Mean Percent Impervious } \\
\text { Surface Cover }\end{array}$ \\
\hline Middle Fork & $65,376,000$ & $24.62 \%$ \\
\hline South Fork & $67,692,600$ & $37.62 \%$ \\
\hline
\end{tabular}




\section{FIGURES}

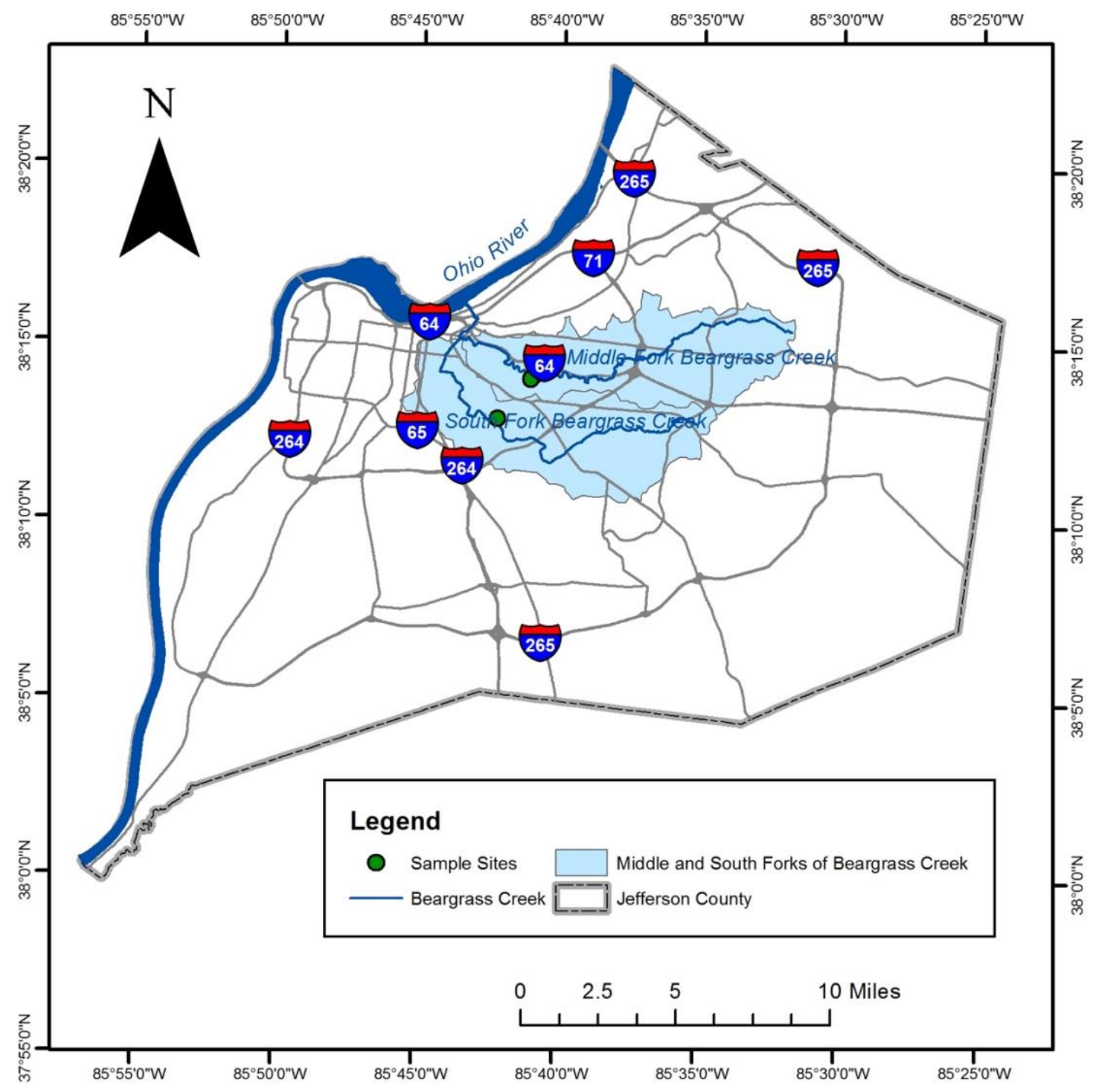

Figure 1. Sample Site Location Map. Middle and South Forks of Beargrass Creek in Jefferson County, Kentucky. Sample sites shown in each fork; blue border indicates the watershed for each fork. 


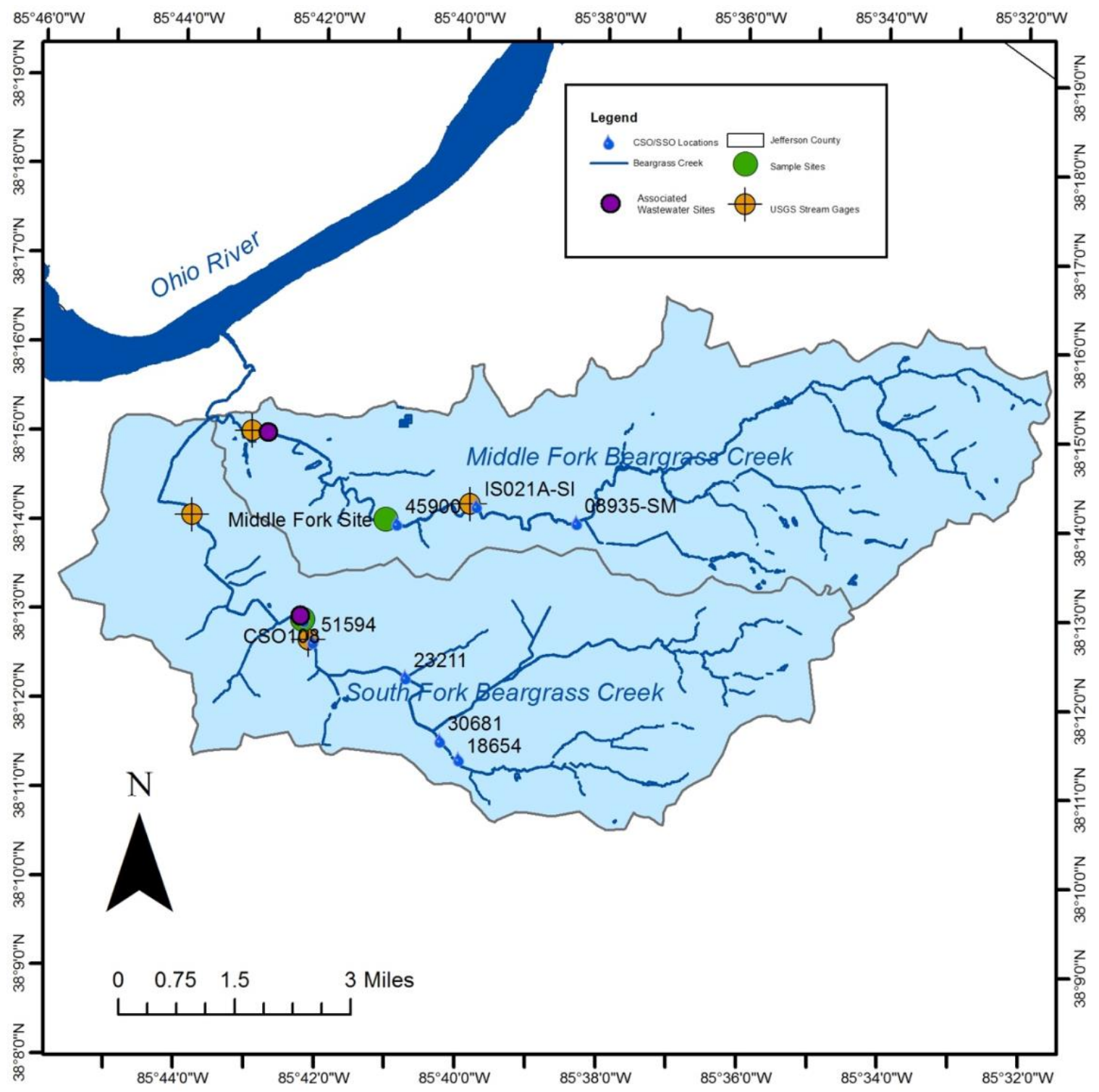

Figure 2. Metro Sewer District and USGS stream monitoring locations, sample site locations, and combined sewer and sanitary sewer locations. 


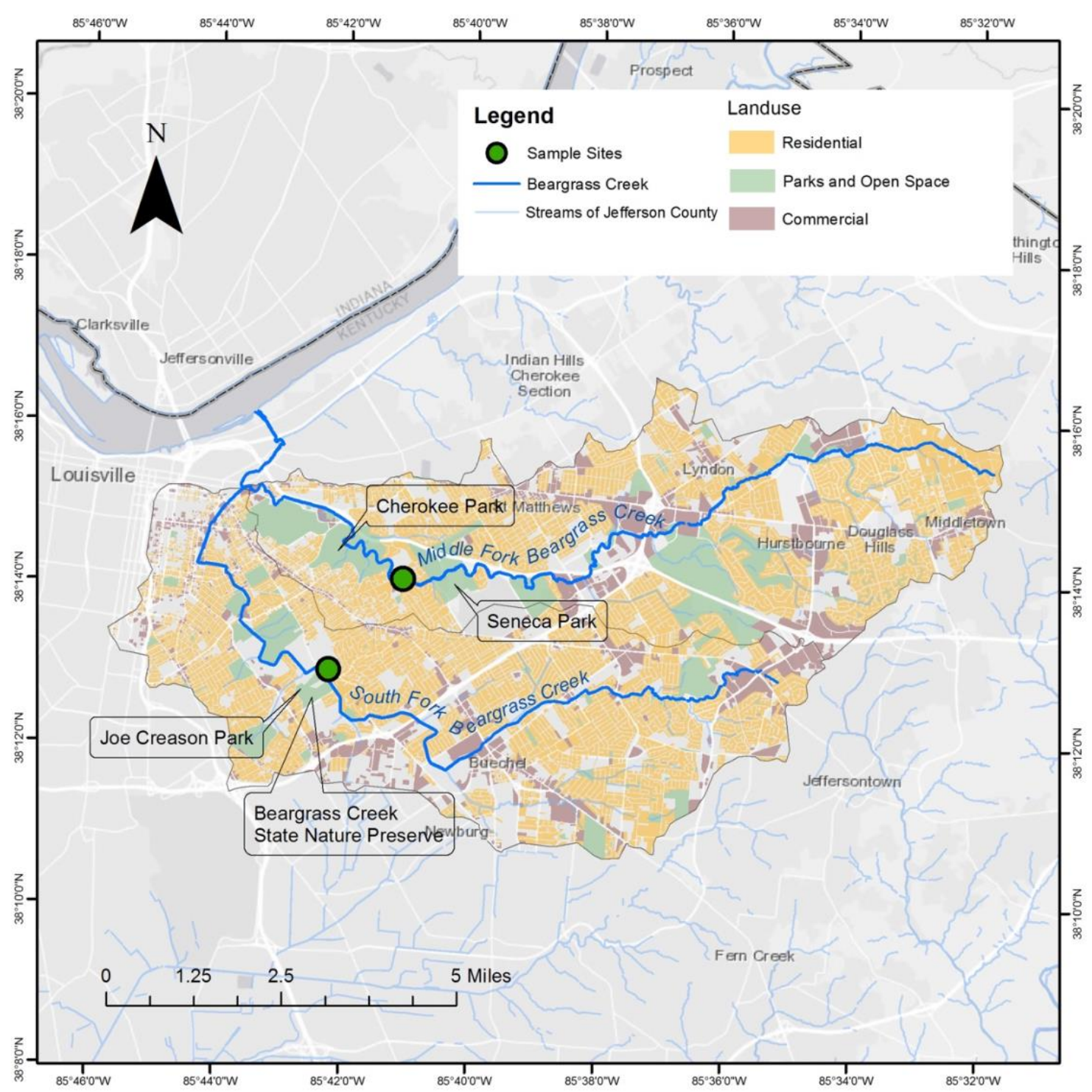

Figure 3. Land use of Middle and South Forks of Beargrass Creek. Relevant parks are labeled. 


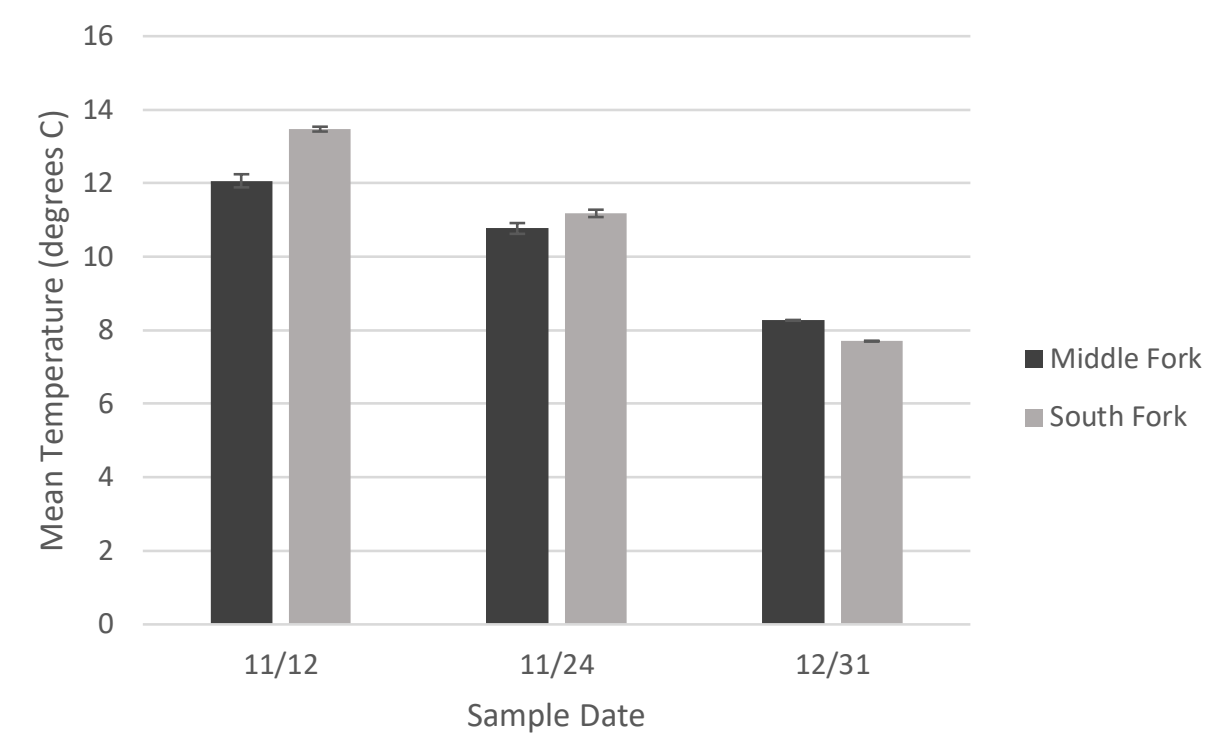

Figure 4. Mean Temperature for the Middle and South Forks of Beargrass Creek $(\mathrm{N}=30)$. Bars represent standard error bars. November $12^{\text {th }} \mathrm{p}<0.0001$; November $24^{\text {th }} p=0.2323$; December $31^{\text {st }} p=0.0066$.

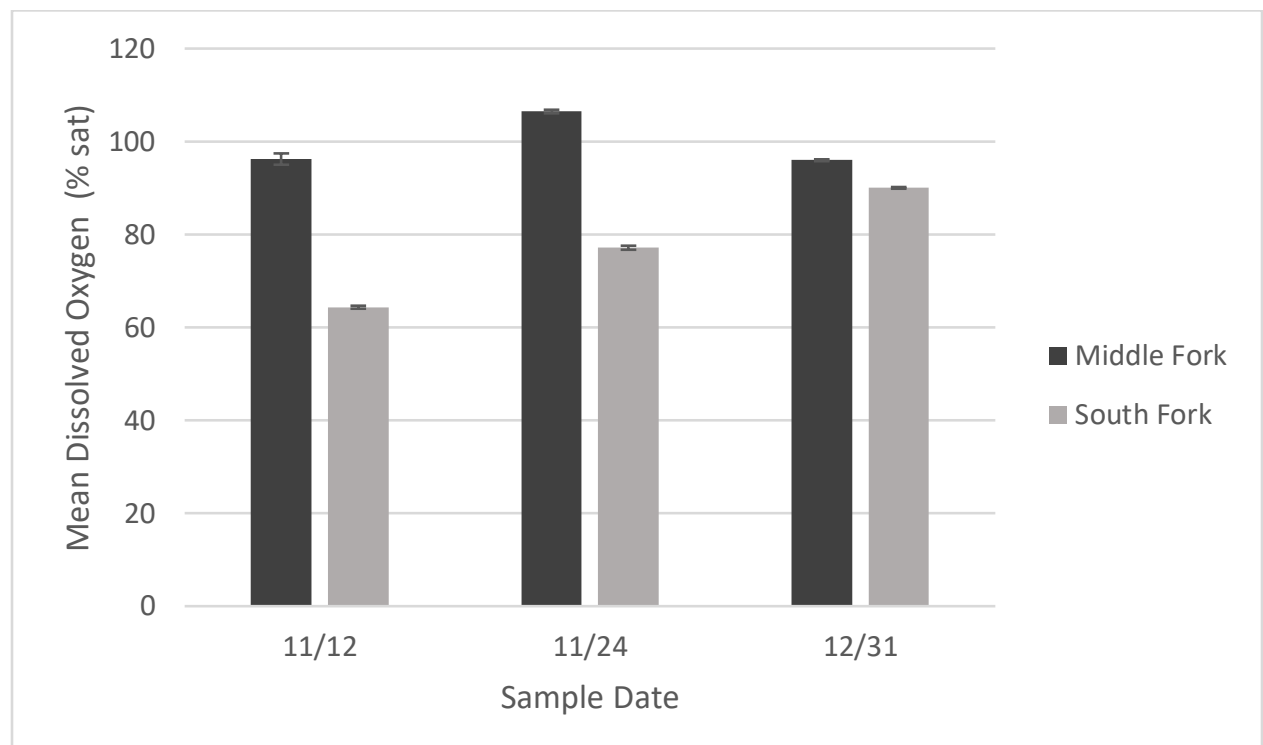

Figure 5. Mean Dissolved Oxygen (\% saturation) across three dates in the Middle and South Forks of Beargrass Creek ( $\mathrm{N}=30)$. Bars represent standard error bars. November $12^{\text {th }} p<0.0001$; November $24^{\text {th }} p<0.0001$; December $31^{\text {st }}$ $\mathrm{p}<0.0001$. 


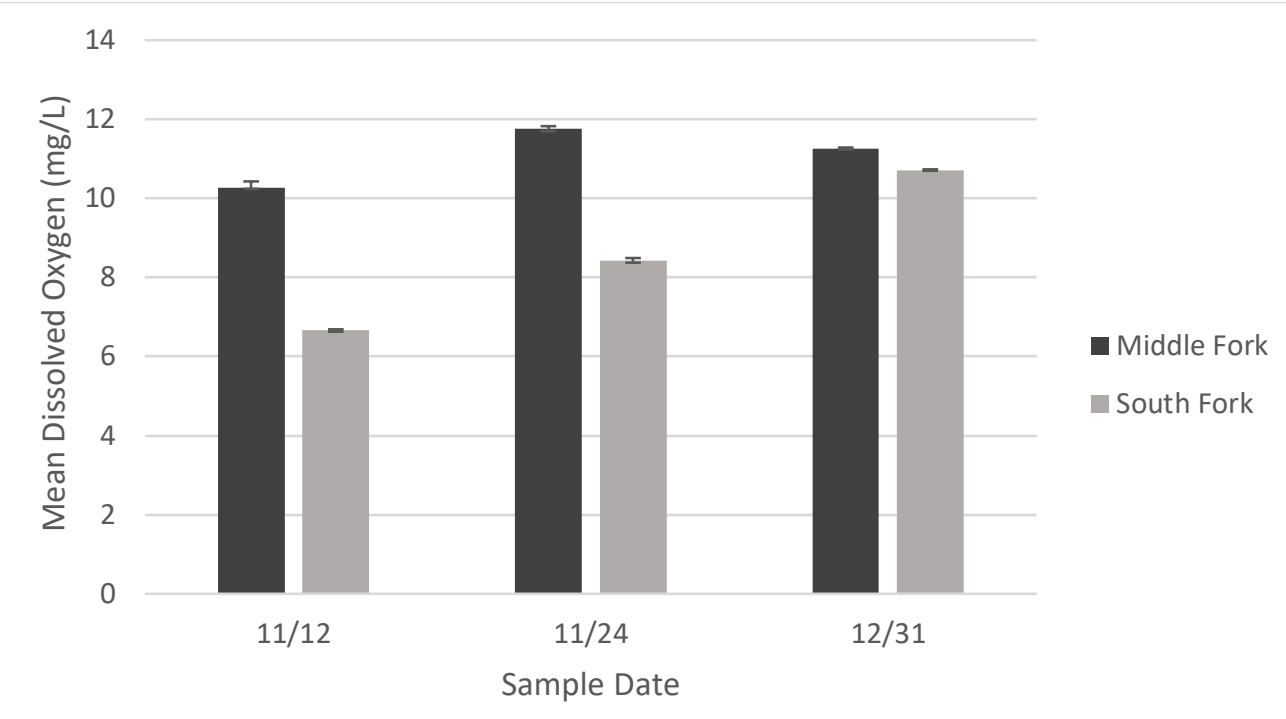

Figure 6. Mean Dissolved Oxygen ( $\mathrm{mg} / \mathrm{L}$ ) across three sample dates for Middle Fork and South Forks of Beargrass Creek $(\mathrm{N}=30)$. Bars represent standard error bars. November $12^{\text {th }} p<0.0001$; November $24^{\text {th }} p<0.0001$; December $31^{\text {st }} p=$ 0.0013 .

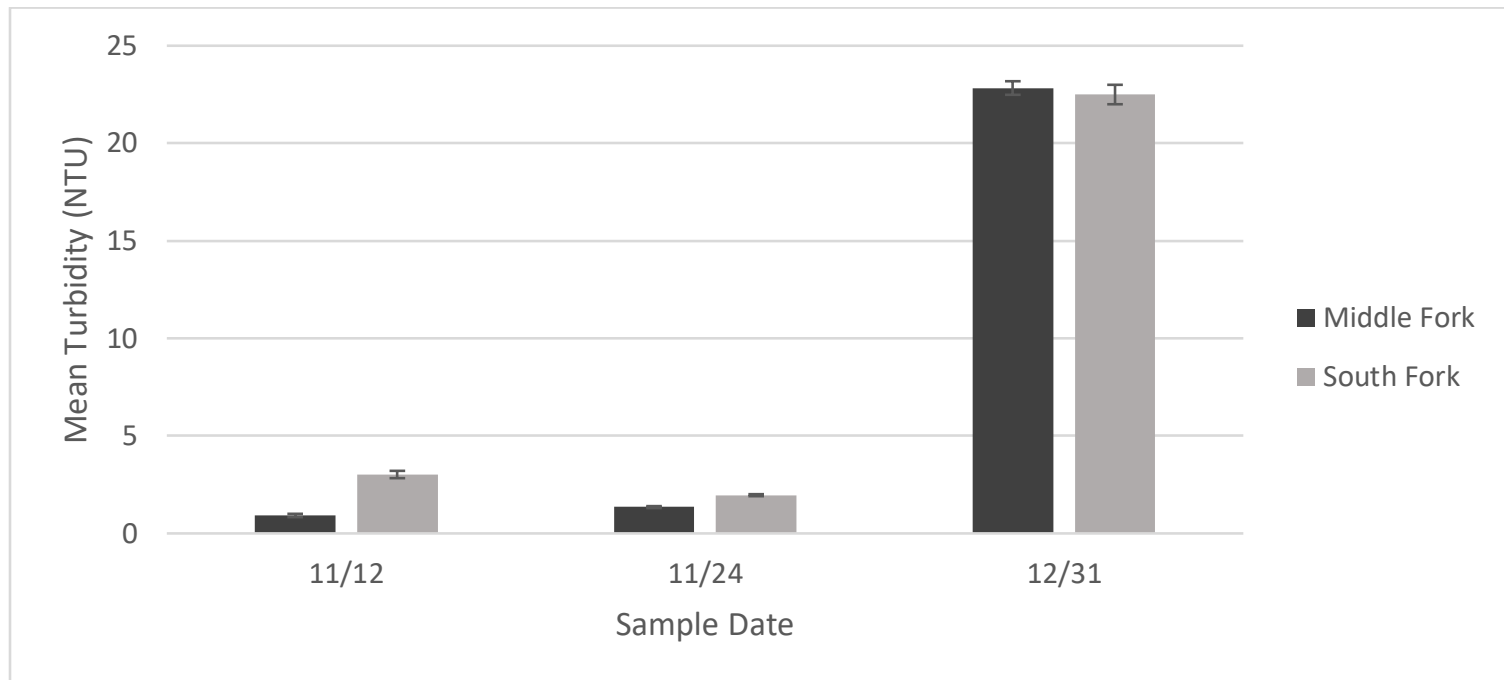

Figure 7. Mean Turbidity (NTU) across three sample dates for the Middle and South Forks of Beargrass Creek $(\mathrm{N}=30)$. Bars represent standard error bars. The Middle Fork and South Forks were found to be significantly different $(p=0.046)$. 


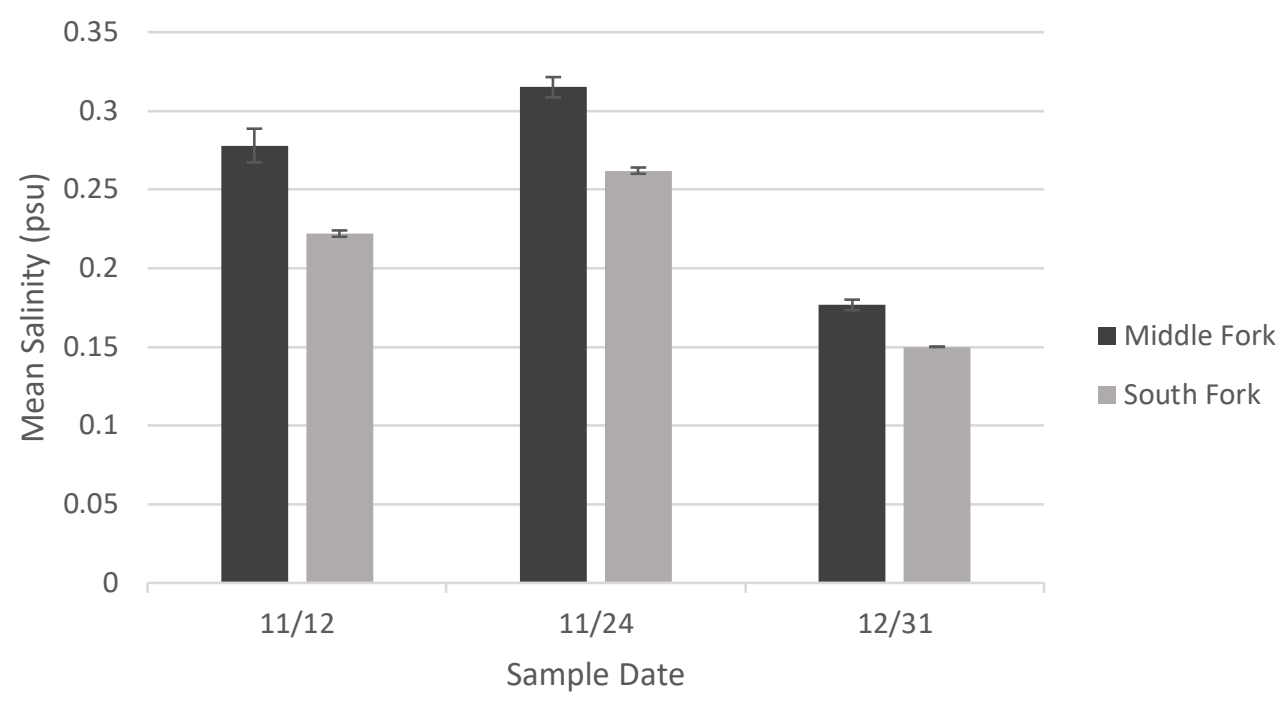

Figure 8. Mean Salinity (psu) across three dates in the Middle Fork and South Forks of Beargrass Creek $(\mathrm{N}=30)$. Bars represent standard error bars. November $12^{\text {th }} p<0.0001$; November $24^{\text {th }} p<0.0001$; December $31^{\text {st }} p<0.0001$.

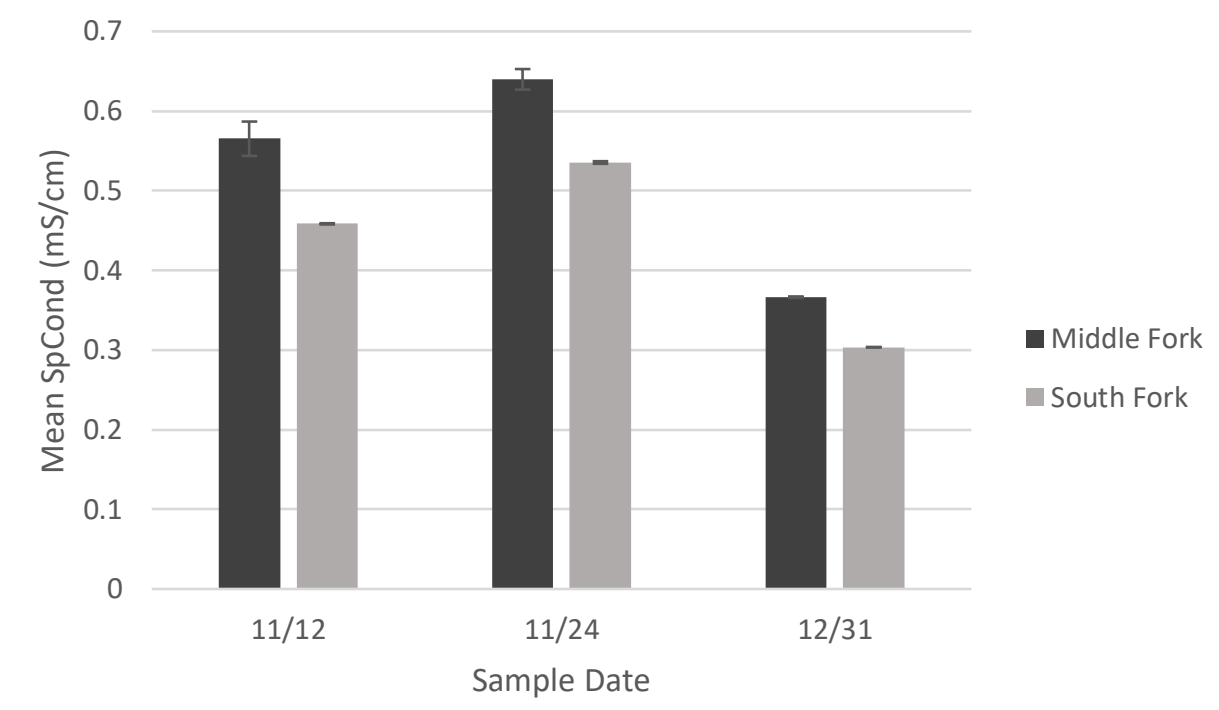

Figure 9. Mean Specific Conductivity $(\mu \mathrm{S} / \mathrm{cm})$ across three dates in the Middle and South Forks of Beargrass Creek $(\mathrm{N}=30)$. Bars represent standard error bars. November $12^{\text {th }} p<0.0001$; November $24^{\text {th }} p<0.0001$; December $31^{\text {st }} p=$ 0.0019 . 


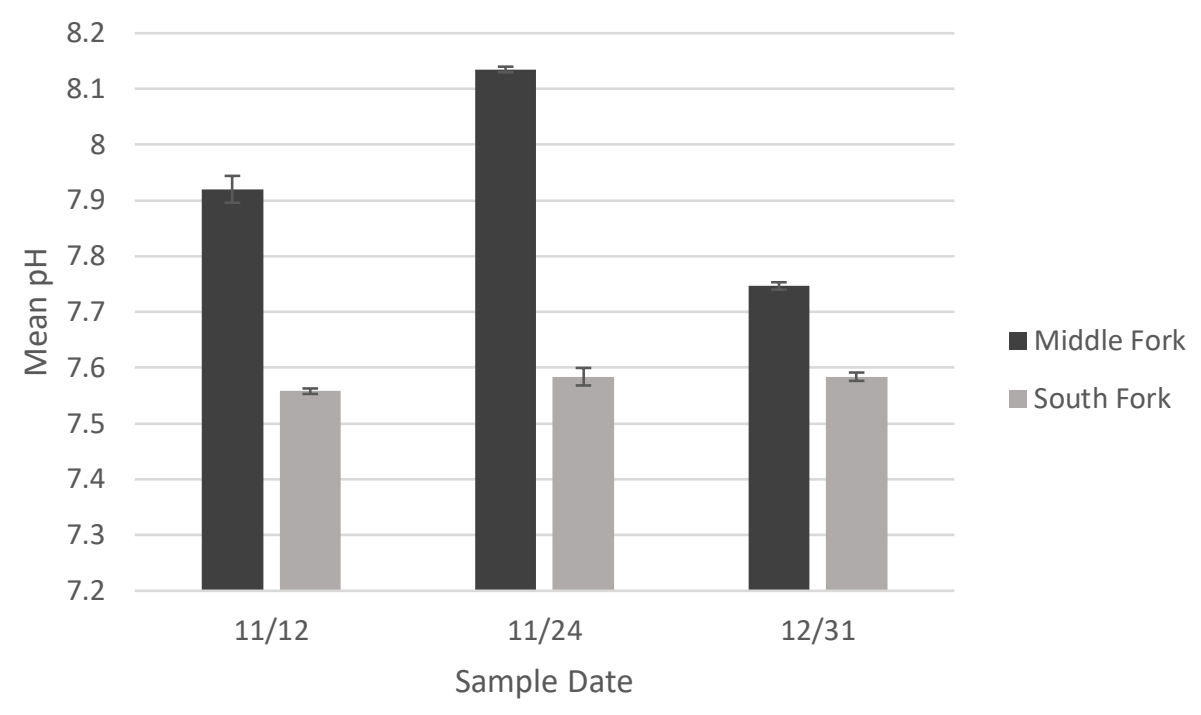

Figure 10. Mean $\mathrm{pH}$ across three dates in the Middle and South Forks of Beargrass Creek $(\mathrm{N}=30)$. Bars represent standard error bars. The Middle and South Forks were found to be significantly different $(p<0.0001)$.

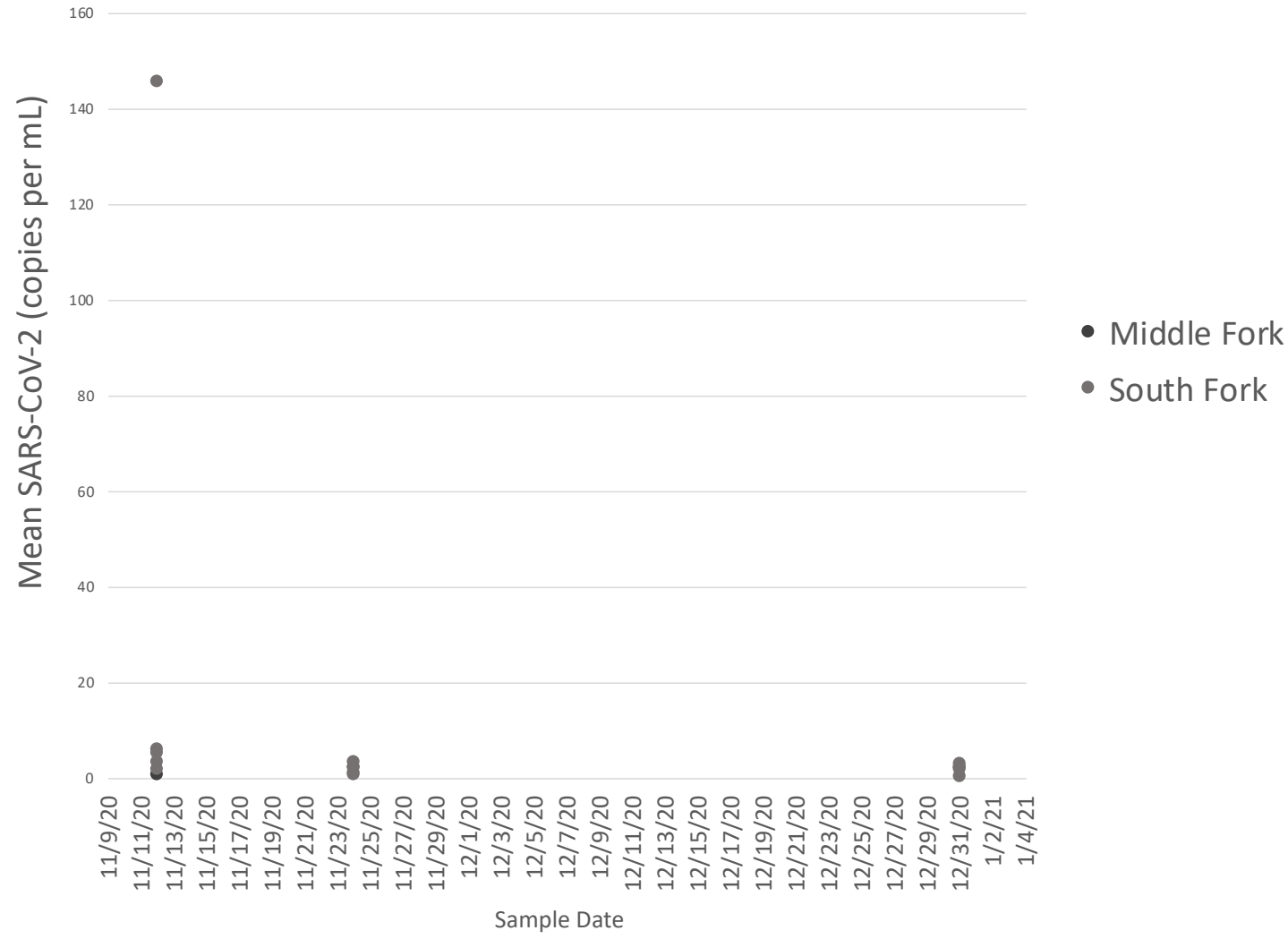

Figure 11. Mean SARS-CoV-2 (copies per $\mathrm{mL}$ ) across three dates in the Middle and South Forks of Beargrass Creek $(\mathrm{N}=27)$. November $12^{\text {th }} \mathrm{p}=0.5983$; November $24^{\text {th }} p=1.0$; December $31^{\text {st }} p=1.0$. 


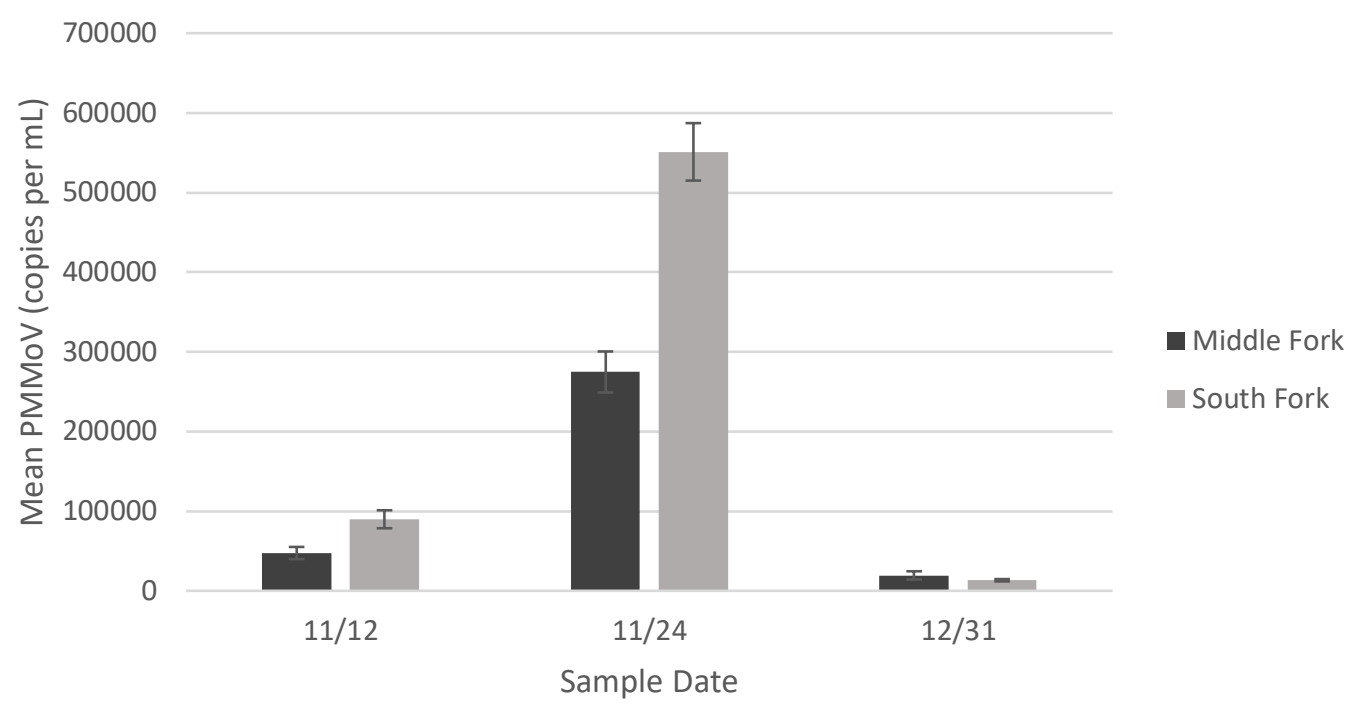

Figure 12. Mean PMMoV (copies per $\mathrm{mL}$ ) across three sample dates for Middle and South Forks of Beargrass Creek $(\mathrm{N}=27)$. Bars represent standard error bars. November $12^{\text {th }} p=0.0356$; November $24^{\text {th }} p=0.0345$; December $31^{\text {st }} p=$ 0.7645 .

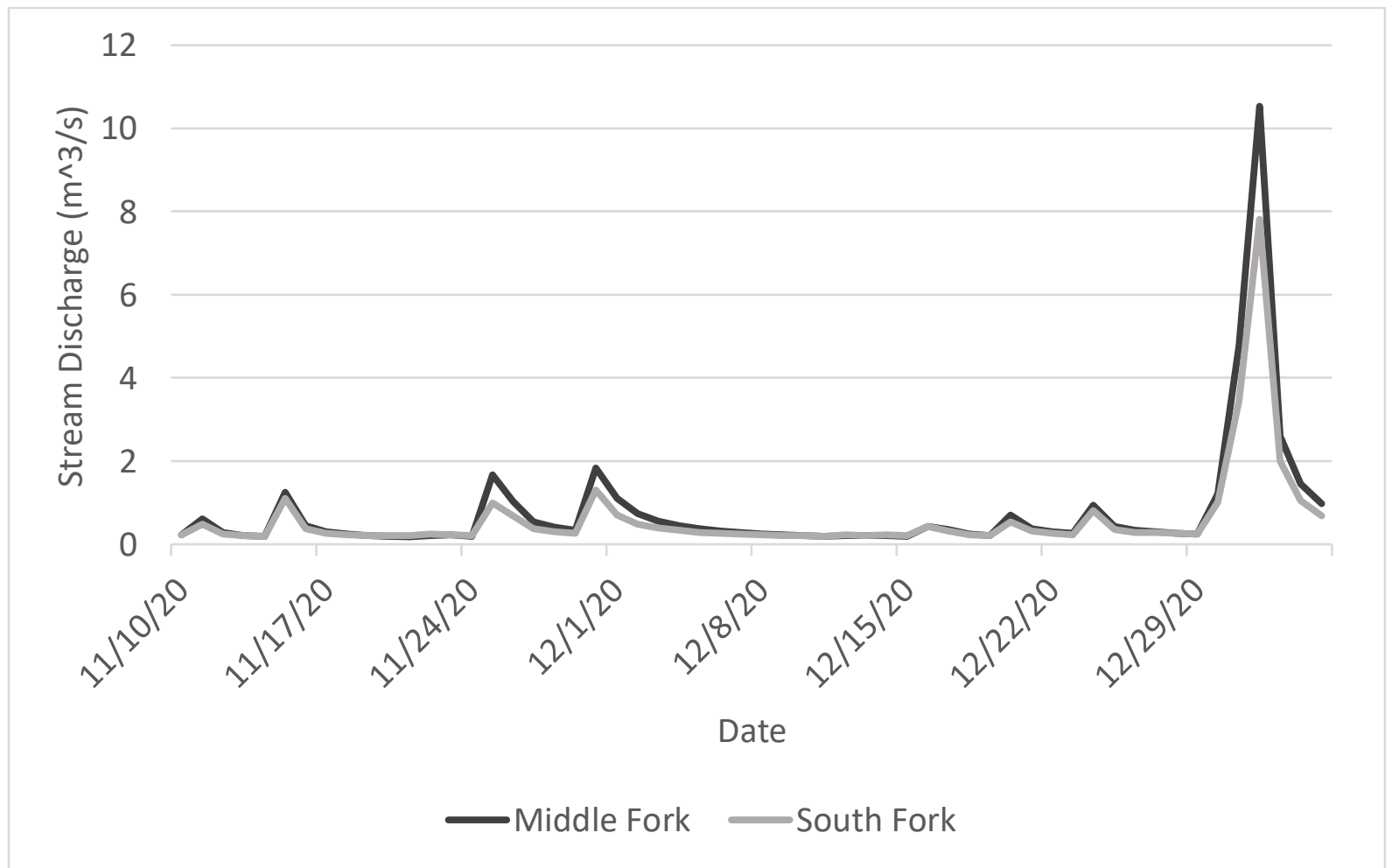

Figure 13. Daily Stream Discharge of Middle and South Forks of Beargrass Creek, highlighting only the days of study sampling. USGS monitoring location 3293000 was used for the Middle Fork and USGS monitoring location 3292500 was used for the South Fork. 


\section{REFERENCES}

Abduljauwad, S.N., Habib, T., \& Ahmed, H. (2020). Nano-clays as potential pseudo-antibodies for COVID-19. Nanoscale Research Letters, 15(173). https://doi.org/10.1186/s11671-020-03403-z

Aguiar-Olivera, M.L., Campos, A., Matos, A.R., Rigotto, C., Sotero-Martins, A., Teixiera, P., F., P., \& Siquiera, M., M. (2020, December). Wastewaterbased epidemiology (WBE) and viral detection in polluted surface water: a valuable tool for COVID-19 surveillance - a brief review. International Journal of Environmental Research and Public Health, 17(1925). http://doi.org/10.3390/ijerph17249251

Ahmed, W., Angel, N., Edson, J., Bibby, K., Bivins, A., O'Brien, J.W., Choi, P. M., Kitajima, M., Simpson, S.L., Li, J., Tscharke, B., Verhagen, R., Smith, W., J.M., Zuagg, J., Dierens, L., Hugenholtz, P., Thomas, K. V., \& Mueller, J. F. (2020). First confirmed detection of SARS-CoV-2 in untreated wastewater in Australia: A proof of concept for the wastewater surveillance of COVID-19 in the community. Science of the Total Environment, 728. https://doi.org/10.1016/j.scitotenv.2020.138764

Ahmed, W., Tscharke, B., Bertsch, P.M., Bibby, K., Bivins, A., Choi, P., Clarke, L., Dwyer, J., Edson, J., Nguyen, T.M.H., O’Brien, J., W., Simpson, S.L., Sherman, P., Thomas, K.V., Verhagen, R., Zuagg, J., \& Mueller, J.F. (2021). SARS-CoV-2 RNA monitoring in wastewater as a potential early warning system for COVID-19 transmission in the community: A temporal case study. Science of the Total Environment, 761. https://doi.org/10.1016/j.scitotenv.2020.144216

ArcGIS Desktop 10.6.1. (2018). ArcMap. ESRI. 380 New York Street Redlands, California

Arnone, R.D., \& Walling, J.P. (2006). Evaluating Cryptosporidium and Giardia concentrations in combined sewer overflow. Journal of Water and Health, 4(2). http://iwaponline.com/jwh/article-pdf/4/2/157/396442/157.pdf

Aurora, S., Nag, A., Sethi, J., Rajvanshi, J., Saxena, S., Shrivastava, S. K., \& Gupta, A. B. (2020). Sewage surveillance for the presence of SARS-CoV2 genome as a useful wastewater based epidemiology (WBE) tracking tool in India. Water Science \& Technology, 82(12). 
http://iwaponline.com/wst/article-

pdf/82/12/2823/803157/wst082122823.pdf

Autixier, L., Mailhot, A., Boldoc, S., Madoux-Humery, A., Galarneau, M., Prevost, M., \& Dorner, S. (2014). Evaluating rain gardens as a method to reduce the impact of sewer overflows in sources of drinking water. Science of the Total Environment, 499. http://dx.doi.org/10.1016/j.scitotenv.2014.08.030

Bandala, E. R., Kruger, B. R., Cesarino, I., Leao, A. L., Wijesiri, B., \& Goonetilleke, A. (2021). Impacts of COVID-19 pandemic on the wastewater pathway into surface water: a review. Science of the Total Environment, 774(145586).

https://doi.org/10.1016/j.scitotenv.2021.145586

Bilotta, G.S., \& Brazier, R.E. (2008). Understanding the influence of suspended solids on water quality and aquatic biota. Water Research, 42, 2849-2861. http://doi.org/10.1007/s11270-017-3505-3

Bitton, G. (1974). Adsorption of viruses onto surfaces in soil and water. Water Research 9, 473-484.

Bivins, A., Greaves, J., Fischer, R., Yinda, C., K., Ahmed, W., Kitajima, M., Munster, V., \& Bibby, K. (2020). Persistence of SARS-CoV-2 in water and wastewater. Environmental Science and Technology Letters, 7, 937-942. https://dx.doi.org/10.1021/acs.estlett.0c00730

Bhowmick, G. D., Dhar, D., Nath, D., Ghangrekar, M. M., Banerjee, R., Das, S., \& Chatterjee, J. (2020). Coronavirus disease 2019 (COVID-19) outbreak: some serious consequences with urban and rural water cycle. Nature Partner Journals, 3(32). https://doi.org/10.1038/s41545-020-0079-1

Bockheim, J.G., and Hartemink, A.E. (2013). Soils with fragipans in the USA. Elsevier: Catena 104, 233-242. http://dx.doi.org/10.1016/j.catena.2012.11.014

Bogler, A., Packman, A., Furman, A., Gross, A., Kushmaro, A., Ronen, A., Dagot, C., Hill, C., Vaizel-Ohayon, D., Morgenroth, E., Bertuzzo, E., Wells, G., Kiperwas, H. R., Horn, H., Negev, I., Zucker, I., Bar-Or, I., Moran-Gilad, J., Balcazar, J.L., ...\& Bar-Zeev, E. (2020). Rethinking wastewater risks and monitoring in light of the COVID-19 pandemic. Nature Sustainability, 3, 981-990. https://doi.org/10.1038/s41893-020-00605-2

Booth, D.B. (2005). Challenges and prospects for restoring urban streams: a perspective from the Pacific Northwest of North America. Journal of the North American Benthological Society 24(3), 724-737. https://www.jstor.org/stable/10.1899/04-025.1 
Brett, J.R. (1956). Some principles in the thermal requirements of fishes. The Quarterly Review of Biology, 31 (2), 75-87.

https://www.jstor.org/stable/2815121

Cañedo-Argüelles, M., Kefford, B. J., Piscart, C., Prat, N., Schäfer, R. B., \& Schulz, C-J. (2013). Salinisation of rivers: An urgent ecological issue. Environmental Pollution, 173, 157-167. http://dx.doi.org/10.1016/j.envpol.2012.10.011

Capone, D., Cumming, O., Nichols, D., \& Brown, J. (2020). Water and sanitation in urban America, 2017-2019. American Journal for Public Health, 110, 1576-1572. http://doi.org/ 10.2105/AJPH.2020.305833

Carmen, N. B., Hunt, W. F., \& Anderson, A. R. (2016). Volume reduction provided by eight residential disconnected downspouts in Durham, North Carolina. Journal of Environmental Engineering, 142(10). http://doi.org/10.1061/(ASCE)EE.1943-7870.0001107

Carpenter, S. R., Caraco, N.F., Correll, D.L., Howarth, R. W., Sharpley, A. N., \& Smith, V. H. (1998). Nonpoint pollution of surface waters with phosphorus and nitrogen. Ecological Society of America, 8(3), 559-568. https://www.jstor.org/stable/2641247

Centers for Disease Control. (2021a). COVID Data Tracker. Retrieved April 14, 2021, from https://covid.cdc.gov/covid-data-tracker/\#county-view

---- (2021b). Symptoms of Coronavirus. Retrieved February 28, 2021, from https://www.cdc.gov/coronavirus/2019ncov/symptoms-testing/symptoms.html

---- (2021c). How COVID-19 Spreads. Retrieved February 28, 2021, from https://www.cdc.gov/coronavirus/2019ncov/prevent-getting-sick/how-covid-spreads.html

---- (2021d). National Wastewater Surveillance System (NWSS). Retrieved February 28, 2021, from https://www.cdc.gov/coronavirus/2019-ncov/cases-updates/wastewatersurveillance.html

Chambers, P.A., McGoldrick, D.J., Brua, R.B., Vis, C., Culp, J.M., Benoy, G.A. (2012). Development of Environmental Thresholds for Nitrogen and Phosphorus in Streams. Journal of Environmental Quality, 41, 7-20. http://doi.org/10.2134/jeq2010.0273 
Chan, K-H., Sridhar, S., Zhang, R. R., Chu, H., Fung, A. Y-F., Chan, G., Chan, J. F-W., To, K. K-W., Hung, I. F-N., Cheng, V. C-C., \& Yuen, K-Y. (2020). Factors affecting stability and infectivity of SARS-CoV-2. Journal of Hospital Infection, 106, 226-231. https://doi.org/10.1016/j.jhin.2020.07.009

Chin, A. W. H., Chu, J. T. S., Perera, M. R. A., Hui, K. P. Y., Yen, H-L., Chan, M. C. W., Peiris, M., \& Poon, L. L., M. (2020). Stability of SARSCoV-2 in different environmental conditions. School of Public Health, University of Hong Kong. https://www.thelancet.com/journals/lanmic/article/PIIS2666$5247 \% 2820 \% 2930003-3 / f u l l t e x t$

City of Milwaukee Department of Public Works. (n.d.) Private property infiltration \& inflow reduction program. Retrieved March 27, 2021, from https://city.milwaukee.gov/dpw/infrastructure/EnvironmentalSection/InflowReduction-Program

Conway, T. M. (2007). Impervious surface as an indicator of $\mathrm{pH}$ and specific conductance in the urbanizing coastal zone of New Jersey, USA. Journal of Environmental Management, 85, 308-316. doi:10.1016/j.jenvman.2006.09.023

Daughton, C. (2020). The international imperative to rapidly and inexpensively monitor community-wide Covid-19 infection status and trends. Science of the Total Environment, 726. https://doi.org/10.1016/j.scitotenv.2020.138149

Day, C. A. and Seay, G. (2020). Impacts of storm characteristics on generating sanitary sewer overflow (SSO) events for an urban sewershed. Papers in Applied Geography, 6(4), 460-470. http://doi.org/10.1080/23754931.2020.1755886

de Oliveira, L. C., Torres-Franco, A., Lopes, B. C., da Silva Santos, B. S. A., Costa, E. A., Costa, M. S., Reis, M. T., Melo, M. C., Polizzi, R. B., Teixeira, M. M., \& Mota, C. R. (2021). Viability of SARS-CoV-2 in river water and wastewater at different temperatures and solids content. Water Research, 195. https://doi.org/10.1016/j.watres.2021.117002

Dosskey, M. G., Vidon, P., Gurwick, N. P., Allan, C. J., Duval, T. P., \& Lowrance, R. (2010). The role of riparian vegetation in protecting and improving chemical water quality in streams. Journal of the American Water Resources Association, 46(2) 261-277. https://doi.org/10.1111/j.17521688.2010.00419.x

Egnew, N., Renukdas, N., Ramena, Y., Yadav, A. K., Kelly, A. M., Lochmann, R. T., \& Sinha, A. K. (2019). Physiological insights into largemouth bass 
(Micropterus salmoides) survival during long-term exposure to high environmental ammonia. Aquatic Toxicology 207, 72-82.

https://doi.org/10.1016/j.aquatox.2018.11.027

Environmental Protection Agency. (1983, July). Municipal Wastewater Disinfection: Proceedings of Second National Symposium. Municipal Environmental Research Laboratory.

https://nepis.epa.gov/Exe/ZyNET.exe/9100PSZ6.TXT?ZyActionD=ZyDocu ment\&Client=EPA\&Index $=1981+$ Thru+1985\&Docs $=\&$ Query $=\&$ Time $=\&$ End Time $=\&$ SearchMethod $=1 \&$ TocRestrict $=$ n\&Toc $=\&$ TocEntry $=\& Q F i e l d=\& Q F i$ eldYear $=\& Q$ FieldMonth $=\& Q$ FieldDay $=\&$ IntQFieldO $p=0 \&$ ExtQFieldOp $=0 \&$ XmIQuery=\&File=D\%3A\%5Czyfiles\%5CIndex\%20Data\%5C81 thru85\%5C Txt\%5C00000019\%5C9100PSZ6.txt\&User=ANONYMOUS\&Password=an onymous\&SortMethod=h\%7C-

\&MaximumDocuments $=1$ \&FuzzyDegree $=0$ \&ImageQuality $=r 75 \mathrm{~g} 8 / \mathrm{r} 75 \mathrm{~g} 8 / \mathrm{x} 1$ 50y150g16/i425\&Display=hpfr\&DefSeekPage=x\&SearchBack=ZyActionL \&Back=ZyActionS\&BackDesC=Results\%20page\&MaximumPages $=1 \& Z y E$ ntry $=1 \&$ SeekPage $=x \& Z y P U R L$

---- (1994, April). Combined Sewer Overflow (CSO) Policy; Notice. Federal Register, 59(75), 18688-18698. Retrieved February 12, 2021, https://www3.epa.gov/npdes/pubs/owm0111.pdf

---- (2002, December). Kentucky Straight Pipes Report: Harlan, Martin, and Bath Counties. Retrieved February 8, 2021, from https://www.epa.gov/sites/production/files/2015-06/documents/20021107.pdf

---- (2020a, June 11). EPA's sars-cov-2 research: Assessing virus levels in sewage for community level screening. Retrieved February 08, 2021, from https://www.epa.gov/sciencematters/epas-sars-cov-2-research-assessingvirus-levels-sewage-community-level-screening

---- (2020b, August 14). Sanitary Sewer Overflows (SSOs). Retrieved February 28, 2021, from https://www.epa.gov/npdes/sanitary-sewer-overflows-ssos

---- (2020c, September 09). Laws \& Regulations: Summary of the Clean Water Act. Retrieved March 10, 2021, from https://www.epa.gov/lawsregulations/summary-clean-water-act

---- (2020d). 401 KAR 10:031. Surface water standards. Retrieved April 1, 2021, from https://www.epa.gov/sites/production/files/201412/documents/kywqs-standards.pdf

---- (2021). Federal Consent Decree. Retrieved February $10^{\text {th }}, 2021$, from https://www.msdprojectwin.org/about-us/federal-consent-decree/ 
Fontenele, R. S., Kraberger, S., Hadfield, J., Driver., E. M., Bowes., D., Holland, L. A., Faleye., T. O. C., Adhikari, S., Kumar, R., Inchausti, R., Holmes, W., K., Deitrick, S., Brown, P., Duty, D., Smith, T., Bhatnagar, A., Yeager II, R. A., Constantine, T., Wilson, M. A., Lim, E. S., Jiang, X., Halden, R. U, Scotch, M., \& Varsani, A. (2021, January). High-throughput sequencing of SARS-CoV-2 in wastewater provides insights into circulating variants. MedRxiv Preprint. https://doi.org/10.1101/2021.01.22.21250320

Gee, G. C. \& Payne-Sturges, D. C. (2004). Environmental Health Disparities: A framework integrating psychosocial and environmental concepts. Environmental Health Perspectives, 112(17), 1645-1653. https://www.jstor.org/stable/3435896

Gerrity, D., Papp, K., Stoker, M., Sims, A., \& Frehner, W. (2021). Early-pandemic wastewater surveillance of SARS-CoV-2 in Southern Nevada: Methodology, occurrence, and incidence/prevalence considerations. Water Research X, 10. https://doi.org/10.1016/j.wroa.2020.100086

Gonzalez, R., Curtis, K., Bivins, A., Bibby, K., Weir, M.H, Yetka, K., Thompson, H., Keeling, D., Mitchell, J., \& Gonzalez, D. (2020). COVID-19 surveillance in Southeastern Virginia using wastewater-based epidemiology. Water Research, 186. https://doi.org/10.1016/j.watres.2020.116296

Grimm, N. B., Grove, J.M., Pickett, S. T. A., \& Redman, C.L. (2005). Integrated approaches to long-term studies of urban ecological systems. BioScience, 50 (7).

Guerrero-Latorre, L., Ballesteros, I., Villacres-Granda, I., Genoveva Granda, M., Friere-Paspuel, B., \& Rios-Tuoma, B. (2020). SARS-CoV-2 in river water: Implications in low sanitation countries. Science of the Total Environment. https://doi.org/10.1016/j.scitotenv.2020.140832

Gundy, P. M., Gerba, C. P., and Pepper, I. L. (2009). Survival of coronaviruses in water and wastewater. Food and Environmental Virology, 1, 10-14. http://doi.org/10.1007/s12560-008-9001-6

Hart, O. E., and Halden, R. U. (2020). Computational analysis of SARS-CoV2/COVID-19 surveillance by wastewater-based epidemiology locally and globally: Feasibility, economy, opportunities and challenges. Science of the Total Environment, 730. https://doi.org/10.1016/j.scitotenv.2020.138875

Haramoto, E., Malla, B., Thakali, O., \& Kitajima, M. (2020). First environmental surveillance for the presence of SARS-CoV-2 RNA in wastewater and river water in Japan. Science of the Total Environment, 737. https://doi.org/10.1016/j.scitotenv.2020.140405 
Hata, A., Katayama, H., Kojima, K., Sano, S., Kasuga, I., Kitajima, M., \& Furumai, H. (2014). Effects of rainfall events on the occurrence and detection efficiency of viruses in river water impacted by combined sewer overflows. Science of the Total Environment. http://dx.doi.org/10.1016/j.scitotenv.2013.08.093

Herb, W. R., Janke, B., Mohseni, O., \& Stefan, H. G. (2008). Thermal pollution of streams by runoff from paves surfaces. Hydrological Processes, 22, 987999. http://doi.org/10.1002/hyp.6986

Holm, R. H. (2021, January 19). An introduction to wastewater based epidemiology for SARS-CoV-2. In Christina Lee Brown Envirome Institute and Kentucky Waterways Alliance, Co-Immunity Surface Water Monitoring for SARS-CoV-2 [Webinar]. University of Louisville, Louisville, KY

Kitajima, M., Sassi, H. P., \& Torrey, J. R. (2018). Pepper mild mottle virus as a water quality indicator. Npj Clean Water, 1(1). http://doi.org/10.1038/s41545-018-0019-5

Kentucky Energy and the Environment Cabinet. (2019). Beargrass Creek State Nature Preserve. Retrieved February 10, 2021, from https://eec.ky.gov/Nature-Preserves/Locations/Pages/BeargrassCreek.aspx

Kentucky Water Health Portal. (2001, 2009). Kentucky Division of Water. Retrieved February 17, 2021, from https://watermaps.ky.gov/WaterHealthPortal/

Kentucky Water Resources Research Institute. (2000). PRIDE Water Quality Assessment Report: Problems and Programs. University of Kentucky. https://www.uky.edu/pride/Reports/Report-A.pdf.pdf

Kentucky Watershed Viewer. (n.d.). Retrieved February 08, 2021, from https://eppcgis.ky.gov/watershed/

Kinouchi, T., Yagi, H., \& Miyamoto, M. (2007). Increase in stream temperature related to anthropogenic heat input from urban wastewater. Journal of Hydrology, 335, 78-88. http://doi.org/10.1016/j.jhydrol.2006.11.002

Kolosna, C. \& Spurlock, D. (2019). Uniting geospatial assessment of neighborhood urban tree canopy with plan and ordinance evaluation for environmental justice. Urban Forestry and Urban Greening, 40, 215-223. https://doi.org/10.1016/j.ufug.2018.11.010

Li, C., Peng, C., Chiang, P-C., Cai, Y., Wang, X., \& Yang, Z. (2019). Mechanisms and applications of green infrastructure practices for stormwater control: A 
review. Journal of Hydrology, 568, 626-637. https://doi.org/10.1016/j.jhydrol.2018.10.074

Litofsky, A. L. E. \& Jennings, A. A. (2014). Evaluating rain barrel storm water management effectiveness across climatography zones in the United States. Journal of Environmental Engineering, 140(4). http://doi.org/10.1061/(ASCE)EE.1943-7870.0000815.

Louisville and Jefferson County Information Consortium (LOJIC). (2020). LOJIC Geodatabase. Accessed from University of Louisville Center for GIS servers. Retrieved October 07, 2020, from http://www.lojic.org

LOJIC Online. (2020). Lojic.org. Retrieved April 01, 2021, from https://www.lojic.org/lojic-online

Louisville-Jefferson County Metro Government. (2021). Beargrass Creek Greenway Project. LouisvilleKy.gov. Retrieved March 06, 2021, from https://louisvilleky.gov/government/parks/beargrass-creek-greenwayproject

Maxcy-Brown, J., Elliot, M.A., Krometis, L.A., Brown, J., White, K.D., \& Lall, U. (2021). Making waves: Right in our backyard - surface discharge of untreated wastewater from homes in the Unites States. Water Research, 190. https://doi.org/10.1016/j.watres.2020.116647

McLellan, S. L., Hollis, E.J ., Depas, M. M., Van Dyke, M., Harris, J., \& Scopel, C. O. (2007). Distribution and fate of Escherichia coli in Lake Michigan following contamination with urban stormwater and combined sewer overflows. Journal of Great Lakes Research, 33, 566-580. https://doi.org/10.3394/0380-1330(2007)33[566:DAFOEC]2.0.CO;2

Medema, G., Heijnen, L., Elsinga, G., Italiaander, R., \& Brouwer, A. (2020). Presence of SARS-Coronavirus-2 RNA in sewage and correlation with reported COVID-19 prevalence in the early stage of the epidemic in The Netherlands. Environmental Science and Technology Letters, 7, 511-516. https://dx.doi.org/10.1021/acs.estlett.0c00357

Metropolitan Sewer District. (n.d.). IOAP Projects. Project WIN: Waterways Improvements Now. Retrieved March 26, 2021, from https://apps.lojic.org/msdioapprojects/

----. (2010a). Sanitary Sewer Overflow Fact Sheet: Sewer Manhole 45900 [Fact Sheet]. Retrieved March 21, 2021, from https://www.msdprojectwin.org/wp-content/uploads/2020/11/45900.pdf 
----. (2010b). Sanitary Sewer Overflow Fact Sheet: Sewer Manhole IS021A-SI. [Fact Sheet]. Louisville-Jefferson County Metro Government. Retrieved March 21, 2021, from https://www.msdprojectwin.org/wpcontent/uploads/2020/11/IS021A-SI.pdfb

----. (2010c). Sanitary Sewer Overflow Fact Sheet: Sewer Manhole 08935-SM. [Fact Sheet]. Louisville-Jefferson County Metro Government. Retrieved March 21, 2021, from https://www.msdprojectwin.org/wpcontent/uploads/2020/11/08935-SM.pdf

----. (2010d). Sanitary Sewer Overflow Fact Sheet: Sewer Manhole 51594. [Fact Sheet]. Louisville-Jefferson County Metro Government. Retrieved March 21, 2021, from https://www.msdprojectwin.org/wpcontent/uploads/2020/11/51594.pdf

----. (2010e). Sanitary Sewer Overflow Fact Sheet: Sewer Manhole 23211. [Fact Sheet]. Louisville-Jefferson County Metro Government. Retrieved March 21, 2021, from https://www.msdprojectwin.org/wpcontent/uploads/2020/11/23211.pdf

----. (2010f). Sanitary Sewer Overflow Fact Sheet: Sewer Manhole 30681. [Fact Sheet]. Louisville-Jefferson County Metro Government. Retrieved March 21, 2021, from https://www.msdprojectwin.org/wpcontent/uploads/2020/11/30681.pdf

----. (2013). Combined Sewer Overflow Fact Sheet: CSO108. [Fact Sheet]. Louisville-Jefferson County Metro Government. Retrieved March 21, 2021, from https://www.msdprojectwin.org/wpcontent/uploads/2020/11/CSO108.pdf

----. (2012a). Middle Fork of Beargrass Creek Watershed. Louisville-Jefferson County Metro Government. Retrieved February 08, 2021, from http://www.msdlouky.org/insidemsd/middlebeargrass.htm

----. (2012b). South Fork of Beargrass Creek watershed. Louisville-Jefferson County Metro Government. Retrieved February 15, 2021, from http://www.msdlouky.org/insidemsd/southforkbeargrass.htm

----. (2016a). State of the Streams 2016 Water Quality Synthesis Report. Louisville-Jefferson County Metro Government. https://louisvillemsd.org/sites/default/files/file_repository/2016\%20Synthesi s\%20Report\%20pages\%20FINAL.pdf

----. (2016b). Sanitary Sewer Overflow Fact Sheet: Sewer Manhole 18654. [Fact Sheet]. Louisville-Jefferson County Metro Government. Retrieved March 
21, 2021, from https://www.msdprojectwin.org/wp-

content/uploads/2020/11/18654.pdf

----. (2019, May 24). MSD honored with innovation award. Louisville-Jefferson County Metro Government. Retrieved February 20, 2021, from https://louisvillemsd.org/news/msd-honored-innovation-award

---. (2020a). The Legacy. Retrieved March $27^{\text {th }}$, from https://louisvillemsd.org/about-us/msd-history/legacy

----. (2020b). U.S. Army Corps of Engineers and MSD partner for Beargrass Creek ecosystem study. Retrieved March $27^{\text {th }}$, from http://www.louisvillemsd.org/news/us-army-corps-engineers-and-msdpartner-beargrass-creek-ecosystem-study

----. (2021a). CSO/SSO Map. Louisville-Jefferson County Metro Government. Retrieved March $16^{\text {th }}, 2021$, from https://apps.lojic.org/msdcsossolocations/

----. (2021b). Project WIN Quarterly Report \#61 October 1, 2020 - December 31, 2020 (Appendix A). [Dataset].

----. (2021c). Project WIN Quarterly Report \#61 October 1, 2020 - December 31, 2020 (Appendix B). [Dataset].

Mohapatra, S., Menon, N. G., Mohapatra, G., Pisharody, L., Pattnaik, A., Menon, N. G., Bhukya, P. L., Srivastava, M., Singh, M., Barman, M. K., Gin, K. Y., \& Mukherji, S. (2021). The novel SARS-CoV-2 pandemic: Possible environmental transmission, detection, persistence and fate during wastewater and water treatment. Science of the Total Environment, 765. https://doi.org/10.1016/j.scitotenv.2020.142746

Multi-Resolution Land Characteristics (MRLC). (2016). National Land Cover Database (2016). [Data set]. U.S. Geological Survey. https://www.mrlc.gov

Naddeo, V., \& Liu, H. (2020). Editorial perspectives: 2019 novel CORONAVIRUS (SARS-COV-2): What is its fate in urban water cycle and How can the water research community respond? Environmental Science: Water Research \& Technology, 6(5), 1213-1216. http://doi.org/10.1039/d0ew90015j

Nourinejad, M., Berman, O., \& Larson, R. C. (2020). Placing sensors in sewer Networks: A system to pinpoint new cases of coronavirus. Elsevier: SSRN. https://ssrn.com/abstract=3744179or http://dx.doi.org/10.2139/ssrn .3744179 
Randazzo, W., Truchado, P., Cuevas-Ferrando, E., Simón, P., Allende, A., \& Sánchez, G. (2020). SARS-CoV-2 RNA in wastewater anticipated COVID19 occurrence in a low prevalence area. Water Research, 181. https://doi.org/10.1016/j.watres.2020.115942

Recktenwald, R. (2017). Chapter Four: Water and wastewater service for the Commonwealth of Kentucky. In B. D. Lee, D. I. Carey, \& A. L. Jones (Eds), Water In Kentucky: Natural history, communities, and conservation (pp. 40-53). University Press of Kentucky. https://www.jstor.org/stable/j.ctt1pd2kxw

Reisinger, A.J., Woytowitz, E., Majcher, E., Rosi, E. J., Belt, K. T., Duncan, J. M., Kaushal, S. S., \& Groffman, P. M. (2018). Changes in long-term water quality of Baltimore streams are associated with both gray and green infrastructure. Association for the Sciences of Limnology and Oceanography, 64(S60-S76). http://doi.org/10.1002/Ino.10947

Rimoldi, S. G., Stefani., F., Gigantiello, A., Polesello, S., Comandatore, F., Mileto, D., Maresca, M., Longobardi, C., Mancon, A., Romeri, F., Pagani, C., Cappelli, F., Roscioli, C., Moja, L., Gismondo, M. R., \& Salerno, F. (2020). Presence and infectivity of SARS-CoV-2 virus in wastewaters and rivers. Science of the Total Environment, 744. https://doi.org/10.1016/j.scitotenv.2020.140911

Ruhl, K., and Jarrett, G. L. (1999). Processes affecting dissolved oxygen concentrations in the lower reaches of Middle Fork and the South Fork Beargrass Creek, Jefferson County, Kentucky. U.S. Department of the Interior, U.S. Geological Survey. https://doi.org/10.3133/wri984218

Said, A., Stevens, D.K., \& Sehlke, G. (2004). An Innovative index for evaluating water quality in streams. Environmental Management, 34(3), 406-414. http://doi.org/10.1007/s00267-004-0210-y

Sanitation District No.1 of Northern Kentucky. N.d. Illicit discharges. Managing Northern Kentucky's Wastewater and Storm Water. https://sd1.org/402/llicit-Discharges

Sala-Comorera, L. Reynolds, L. J., Martin, N. A., O'Sullivan, J. J., Meijer, W. G. \& Fletcher, N. F. (2021). Decay of infectious SARS-CoV-2 and surrogates in aquatic environments. Water Research. https://doi.org/10.1016/j.watres.2021.117090

Sassi, H. P., Tuttle, K. D., Betancourt, W. Q., Kitajima, M. \& Gerba, C. P. (2018). Persistence of viruses by qPCR in three effluent-dominated rivers in the western United States. Food Environ. Virol., 10, 297-304. 
Satterthwaite, D., Beard, V. B., Mitlin, D., \& Du, J. (2019). Untreated and unsafe: Solving the urban sanitation crisis in the Global South. World Resources Report.

Simon, K.S., Simon, M.A., \& Benfield, E.F. (2009). Variation in ecosystem function in Appalachian streams along an acidity gradient. Ecological Applications, 19(5), 1147-1160.

Sims, N., \& Kasprzyk-Hordern, B. (2020). Future perspectives of wastewaterbased epidemiology: Monitoring infectious disease spread and resistance to the community level. Environment International, 139.

https://doi.org/10.1016/j.envint.2020.105689

Smith, T., Cassell, G., \& Bhatnagar, A. (2021). Wastewater Surveillance Can Have a Second Act in COVID-19 Vaccine Distribution. JAMA Health Forum, 2(1). American Medical Association. http://doi.org/10.1001/jamahealthforum.2020.1616

Smith, V.H., Joye, S.B., \& Howarth, R.W. (2006). Eutrophication of freshwater and marine ecosystems. Limnology and Oceanography 51 (1) 351-355. https://doi.org/10.4319/lo.2006.51.1_part_2.0351

Stoner, A. (2017). Regulatory deficiencies in wastewater infrastructure in rural Appalachia. Sustainable Development Law and Policy, 18(2), 30-31.

Strifling, D. (2003-2004). Sanitary Sewer Overflows: Past, Present, and Future Regulation. Marquette Law Review, 87, 225-252.

Sun, Y., Deng, L., Pan, S-Y., Chiang, P-C., Sable, S. S., \& Shah, K. J. (2020). Integration of green and gray infrastructures for sponge city: Water and energy nexus. Water-Energy Nexus, 3, 29-40. https://doi.org/10.1016/j.wen.2020.03.003

Sunkari, E. D., Korboe, H. M., Abu, M., \& Kizildeniz, T. (2021). Sources and routes of SARS-CoV-2 transmission in water systems in Africa: Are there any sustainable remedies? Science of the Total Environment, 753. https://doi.org/10.1016/j.scitotenv.2020.142298

Sydmonds, E., M., Rasario, K., \& Breitbart, M. (2019). Pepper mild mottle virus: Agricultural menace turned effective tool for microbial water quality monitoring and assessing (waste)water treatment technologies. PLOS Pathogens, 15(4). https://doi.org/10.1371/journal.ppat.1007639

Taguchi, V. J., Carey, E. S., \& Hunt III, W. F. (2018). Field monitoring of downspout disconnections to reduce runoff volume and improve water 
quality along the North Carolina coast. Journal of Sustainable Water in the Built Environment, 5(1). http://doi.org/10.1061/JSWBAY.0000872

Tavakol-Davani, H., Burian, S. J., M.ASCE, Devkota, J., \& Apul, D. (2015).

Performance and cost-based comparison of green and gray infrastructure to control combined sewer overflows. J. Sustainable Water Built Environment 2(2). DOI: 10.1061/JSWBAY.0000805

Tibbetts, J. (2005). Combined sewer systems: down, dirty, and out of date. Environmental Health Perspectives, 113(7). http://doi.org/10.1289/ehp.113-a464

Tippler, C., Wright, I. A., \& Hanlon, A. (2012). Is catchment imperviousness a keystone factor degrading urban waterways? A case study from a partly urbanised catchment (Georges River, South-Eastern Australia). Water Air Soil Pollution, 223, 5331-5344.

Tran, H. N., Lee, G. T., Nguyen, D. T., Juang, R-S., Rinklebe, J., Bhatnagar, A., Lima, E. C., lqbal, H. M. N., Sarmah, A. K., \& Chao, H-P. (2020). SARSCoV-2 coronavirus in water and wastewater: A critical review about presence and concern. Environmental Research. https://doi.org/10.1016/j.envres.2020.110265

U.S. Census Bureau. (2019). Quick Facts: Jefferson County, Kentucky. [Data set]. U.S. Department of Commerce.

https://www.census.gov/quickfacts/fact/table/louisvillejeffersoncountybalan cekentucky,jeffersoncountykentucky/PST045219

U.S. Environmental Protection Agency v. The Louisville and Jefferson County Metropolitan Sewer District, Case 3:05-cv-00236-CRS. Page \# 1-42 (2005). https://www.msdprojectwin.org/library/\#6-8-2005-consent-decree

U.S. Geological Survey. (2020). Nutrients and Eutrophication. Retrieved April 19th, from, https://www.usgs.gov/mission-areas/waterresources/science/nutrients-and-eutrophication?qtscience_center_objects=0\#qt-science_center_objects

---- (2021a). USGS Surface-Water Daily Data for the Nation: USGS 03293000 M FK BEARGRASS CR AT OLD CANNONS LN AT LOUISVILLE. U.S. Department of the Interior. Retrieved March 21, 2021, from

https://waterdata.usgs.gov/nwis/dv?cb_00060=on\&format=gif_default\&site no $=03293000 \&$ referred_module $=$ sw\&period=\&begin_date $=2020-11$ 08\&end_date=2021-01-05

---- (2021b). USGS Surface-Water Daily Data for the Nation: 
USGS 03292500 SOUTH FORK BEARGRASS CREEK AT LOUISVILLE, $K Y$. U.S. Department of the Interior. Retrieved March 21, 2021, from https://waterdata.usgs.gov/nwis/dv?cb_00060=on\&format=gif_default\&site no $=03292500 \&$ referred_module $=s w \& p e r i o d=\&$ begin_date $=2020-11$ 08\&end_date $=2021-01-04$

Vicente, J., Colmenarejo, M. F., Sanchez, E., Rubio, A., Garcia, M. G., Borja, R., Jimenez, A. M. (2011). Evaluation of the water quality in the Guadarrama river at the section of Las Rozaz-Madrid, Spain. Water and Environmental Journal, 25, 55-66. http://doi.org/10.1111/j.1747-6593.2009.00188.x

Viviano, G., Valsecchi, S., Polsello, S., Capodaglio, A., Tartari, G., \& Salerno, F. (2017). Combined use of caffeine and turbidity to evaluate the impact of CSOs on River Water Quality. Water Air Soil Pollut., 228(330). http://doi.org/10.1007/s11270-017-3505-3

Yaeger, R. A., Holm, R. H., Saurabh, K., Fuqua, J. L., Talley, D., Bhatnagar, A., \& Smith, T. (2020, August). Wastewater sample site selection to estimate geographically-resolved community prevalence of COVID-19: A research protocol. Medrxiv Preprint. https://doi.org/10.1101/2020.08.23.20180224

Yang, X, Wu, X., Hao, H., \& He, Z. (2008). Mechanisms and assessment of water eutrophication. Journal of Zhejiang University, 9(3), 197-209. http://doi.org/10.1631/jzus.B0710626

Yates, M. V., Gerba, C. P, and Kelley, L. M. (1985). Virus persistence in groundwater. Applied and Environmental Microbiology, 49(4), 778-781.

Walsh, C. J., Roy, A. H., Feminella, J. W., Cottingham, P. D., Groffman, P. M. \& Morgan II, R. P. (2005). The urban stream syndrome: a current knowledge and the search for a cure. The North American Benthological Society, 24(3), 706-723.

Walthore, R., Gupta, A., Bherwani, H., \& Labhasetwar, N. (2020). Understanding air and water borne transmission and survival of coronavirus: Insights and way forward for SARS-CoV-2. Science of the Total Environment, 749. https://doi.org/10.1016/j.scitotenv.2020.141486

Wang, X-W., Li, J-S., Jin, M., Zhen, B., Kong, Q-X., Song, N., Xiao, W-J., Yin, J., Wei, W., Wang, G-J., Si, B-Y., Guo, B-Z., Liu, C., Ou, G-R., Wang, MN., Fang, T-Y., Chao, F-H., \& Li, J-W. (2005). Study on the resistance of severe respiratory syndrome-associated coronavirus. Journal of Virology Methods, 126 (171-177). https://doi.org/10.1016/j.jviromet.2005.02.005 
Wang, X., Li, J., Chen, J., Cui, L., Li, W., Gao, X., \& Liu, Z. (2020). Water quality criteria of total ammonia nitrogen (TAN) and un-ionized ammonia $\left(\mathrm{NH}_{3}-\mathrm{N}\right)$ and their ecological risk in the Liao River, China. Chemosphere 243.

https://doi.org/10.1016/j.chemosphere.2019.12532 


\section{APPENDICES}

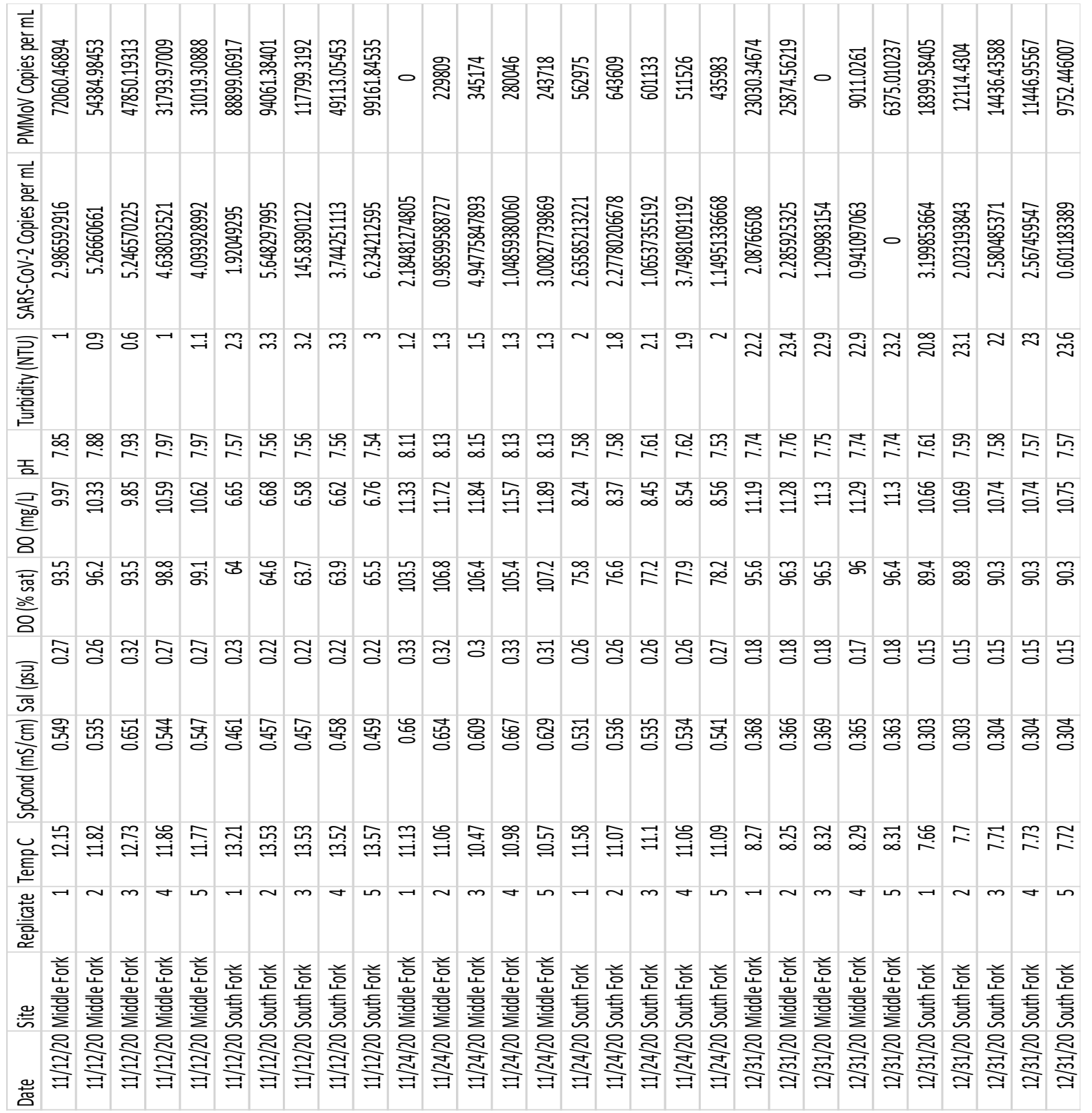

Appendix 1. Raw stream sampling data. Middle and South Forks of Beargrass Creek from November $12^{\text {th }}, 2020$ to December 31 st 2020. 


\section{CURRICULUM VITA}

NAME: Cullen Eileen Hunter

ADDRESS: University of Louisville Urban and Public Affairs 426 W Bloom St Louisville, KY, 40208
Email: culleneileen@yahoo.com Cell: (502) 645-9372

\section{EDUCATION}

University of Louisville: Louisville, KY

Jan 2019 - present

MS in Interdisciplinary Studies: Sustainability

- Curriculum focused on integrating sustainable practices and solutions across disciplines

- Cumulative GPA - 3.97 on a 4.0 scale

DePauw University: Greencastle, IN

Bachelor of Arts in Interdisciplinary Environmental Biology

- Cumulative GPA - 3.56 on 4.0 scale, Cum Laude

\section{DePauw Environmental Fellows Program}

- Honors program focused on a multidisciplinary understanding of environmental issues with academic rigor, community engagement, and capstone experience

Trustee Award, awarded by DePauw University upon acceptance

Dean's List (minimum 3.5 GPA) - five of eight semesters

\section{JOB EXPERIENCE}

STEPS Research Assistant, University of Kentucky, Louisville March 2021- present

- CDC grant to study the prevalence of SARS-COV-2 in wastewater from nursing homes in Louisville, Kentucky

- Operate ISCO composite samplers and conduct field schedule for three sites, field cleaning protocol, and sampling protocol

- Cooperate with staff from nursing homes to arrange sampling dates

Intern: The Co-Immunity Project, Kentucky Waterways Alliance Aug 2020 - present

- Research project created by The Christina Lee Brown Envirome Institute, Metro Sewer District, the University of Louisville, and Kentucky Waterways Alliance to study the prevalence and distribution of COVID-19 in Jefferson County

- Thesis component focused on the presence of SARS-CoV-2 in areas of Beargrass Creek that receive sewer overflows

Intern: Waterfront Botanical Gardens, Avish Estate, Louisville KY

\section{Summer 2019}

- Took care of plants to eventually be planted on the main site of Waterfront Botanical Gardens under the head of Horticulture, facilitated learning activities for field trips, worked with volunteers on a weekly basis 
Customer Service Associate: Lowe's, Louisville KY

- Garden Center associate, documented incoming plant inventory, merchandised plants, mentored and trained lawn and garden new hires, worked directly underneath the Live Nursery Specialist

- May 2018 Employee of the Month

Garden Center Associate: Wallitsch Garden Center, Louisville, KY Customer sales and support, assisted in buying and receiving plant material,
merchandised product, daily register operations, product knowledge

Volunteer: Yew Dell Botanical Gardens, Louisville KY

Sept 2018 - Mar 2019

Jun - Dec 2018

- Completed tasks such as weeding, watering, assistance on projects like the installation of micro irrigation and plant propagation

Plant Merchandiser: Plant Essentials, Louisville KY

Jul - Aug 2017

- Organized plant shipments according to sun/shade requirements, landscaping category, color etc.

Volunteer: Backside Learning Center at Churchill Downs, Louisville KY

- Assistant teacher for Intermediate and Advanced English classes

Jun - Sept 2017

\section{FIELD EXPERIENCE AND RESEARCH}

Introduction to GIS \& Advanced GIS: GEOG 558, GEOG 559, UofL Aug 2019 - May 2020

- Final projects including mapping potential rooftop garden areas in Louisville and land use maps of Beargrass Creek watershed in Jefferson County using LOJIC data and ArcGIS

- Learned ArcGIS tools such as address locator, geocoding, digitizing watersheds, and raster manipulation

Introduction to Remote Sensing: GEOG 555, UofL

Aug - Dec 2020

- Fundamental principles of remote sensing using ENVI software

- Used vegetation indices, calibration techniques, unsupervised and supervised classifications to create land cover classification thematic maps

Sustainable Social and Ecological Systems: PADM 676, UofL

- Semester project researching the social and ecological barriers to implementing a rooftop garden over the Early Learning Campus at UofL

Senior Capstone Research: BIO 490 Research Problems, DePauw Univ.

- Phenology of anthocyanins and chlorophylls in three plant species in the DePauw University Nature Park

- Learned plant pigment extraction techniques, used JMP statistical software for analysis and produced poster summarizing the results of my project

Environmental Fellow Seminar: HONR 422, DePauw Univ.

- Semester research project on anthropological implications of genetically modified organisms

- Interviewed prospective Environmental Fellow students alongside program directors

- Organized and executed a community engagement project focused on the sustainability of a farmhouse deconstruction

Aquatic Ecology: BIO 390, DePauw Univ.

Aug - Dec 2019

- Created and implemented a research project in the DePauw University Nature Park on bottom-up limitations on nutrients in the quarry pond

- Learned to use Van Dorn sampler, plankton tow, Secchi disk, and performed chlorophyll and nutrient extractions

- Composed group research paper and presented at class research symposium

Conservation Biology: BIO 345, DePauw Univ.

- Designed and completed research project in the DePauw University Nature Park on medicinal and edible plants to promote awareness and conservation

- Created pamphlet and brochure for use in the Welcome Center

Aug - Dec 2015 
- Wrote partner paper and presentation for class research symposium

\section{SKILLS}

Attention to detail; punctual; professional

ArcGIS 10.6, ArcCatalogue 10.6, and ArcScene 10.6

Introductory understanding of ENVI 5.5 and ENVI Classic 5.5 remote

sensing software

Basic knowledge of handheld GPS devices (Trimble)

Writing, Creative and Science

Microsoft Office; time management; teamwork 